\title{
Material and Temporal Ambiguity at Santiago de Compostela: The Case of the South Portal's Woman with the Skull
}

Karen Webb

\section{Abstract}

The Romanesque sculpture from Santiago de Compostela's Puerta de las Platerías, known as the Woman with the Skull, presents questions of origin. Using the competing methods of conceptual design prior to material execution and material priority over a conceptual construct which loom large in the portal's formation, iconographical and historical content are related. The question of process points to polemical ideas that suspend the Woman between papal design and royal appropriation. Additionally, she is suspended between categorical identities like Luxuria and fanciful product of the chansons de gestes and historical identities like the wife, sister, and daughter of Alfonso VI.

Keywords: Santiago de Compostela; Woman with the Skull; Puerta de las Platerías; Alfonso VI; Queen Urraca; consanguinity; Investiture Struggle; Original Sin; Ambiguity. 


\title{
Material and Temporal Ambiguity at Santiago de Compostela: The Case of the South Portal's Woman with the Skull
}

\author{
Karen Webb
}

\section{Introduction to the 'Whole'}

\section{The South Portal}

Upon first sight, the south portal of Santiago de Compostela (Fig. 1) immediately relays its relationship to material ambiguity and conceptual ambiguity. The entirety of the south portal at Santiago is composed of broken and reused sculptures, many believed to be added from the north portal over an extended period of time. ${ }^{1}$

\footnotetext{
${ }^{1}$ The fact that some of the sculptures mentioned as placed on the north portal in the Pilgrim's Guide appear today on the south have led scholars to the conclusion that many sculptures from the north portal were moved to the south. A general list of categories of sculpture on the north in the Guide list "Saints, beasts, men, angels, women, flowers, and other creatures." These general categories have also led to some speculation. The example of the Expulsion of Adam and Eve, which appears on the south portal now, and the condition of most of the sculpture with its imprecise edges, lead to similar conclusions. In $1765-1770$, the north portal was renovated as a Neo-classical style façade and it is believed that more of the Romanesque vestiges were taken out of the northern context. The presence of the sculpture from the north on the south side in the Middle Ages is supported by the burning of the transept and the city riots of 1117 . For the evidence of the guide's description, see Paula Gerson, Annie Shaver-Crandell, Alison Stones, and Jeanne Krochalis, ed. and trans. The Pilgrim's Guide: A Critical Edition, Vol. II, The Text: Annotated English Translation (London: Harvey Miller Publishers, 1998), 72, 73. For the eighteenth-century evidence, see A. Fernández González, "Un Viejo plano olvidado en el Archivo de la Catedral de Santiago: la Porta Francigena, su atrio y la Corticela en el año 1739," Compostellanum, XLVIII, 1 - 4 (2003), 701 - 742, esp. fig $1-2,9$. Henri Focillon, L'Art de sculpteurs romans (Paris, 1931), 160.
} 


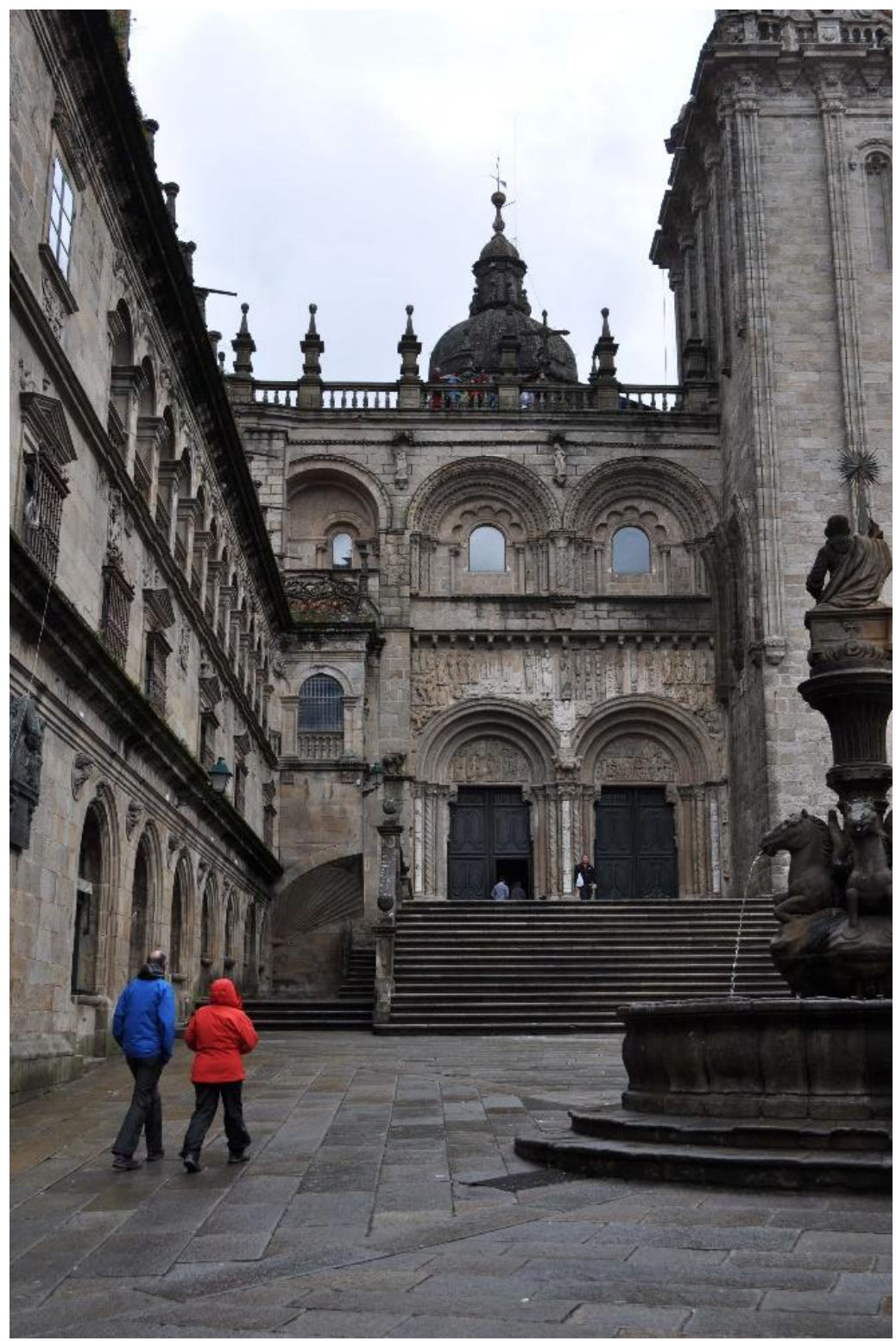

Fig. 1. South Portal of the Cathedral of Santiago de Compostela, Spain (photo: the author) 
Thus, the portal eludes classification inherent in art historical studies and this ambiguity depends upon the violation of rules governing a set construct (here, the "typical" Romanesque portal). With ambiguous objects, a potential result is that the construct precedes the object making ostracism separate the violator from the majority. If the object precedes the construct, this allows there to be potential for the evolution or conversion of the object, materially or conceptually, to fit the new "expectation." This difference makes the idea of the "whole' defined as either a material 'whole' that precedes and is fragmented by a construct or a temporal construct as 'whole' that precedes and fragments a material entity.

At Santiago, the temporal conversion of and influence upon the movement of material sculptures from the north portal to the south portal gradually diminishes the north portal's material presence while augmenting the south portal's material presence. This material change is a temporal merging or conversion of the north into the south. The material ostracism of the north separates and determines the specifically temporal Romanesque style of the sculptural content which moves to the south portal. Thus, in terms of temporal conversion, material is manipulated and in terms of material separation, time is manipulated. Whether this also means that the whole south portal has a constructed organization that predates and becomes realized through the temporal conversion, is an interesting question, but not the central issue to be taken up in this study. This study uses the idea of separation and conversion to consider how universals and particulars like symbolism and history, image and word, material and time, context and object, and category and identity are subject to isolation from one another or superimposition upon one another. The ambiguity that these interactions produce, results in conflict. Of special concern in its impact on the portal is the idea of authoritative ambiguity (royalty and pope), familial ambiguity, and moral ambiguity.

Though erudite and perceptive, in the case of Santiago, Hearn sees no organization or conceptual message in the collection of sculpture due to its singularity in appearance. ${ }^{2}$ Concurring with Focillon's assessment of the portal as a musée lapidaire, the portal is denied equal

\footnotetext{
${ }^{2}$ M. F. Hearn, Romanesque Sculpture: The Revival of Monumental Stone Sculpture in the Eleventh and Twelfth Centuries (Ithaca: Cornell University Press, 1981), 144 - 145. Hearn calls it a "meaningless jumble."
} 
status as a complete object to other portals, largely due to its nonoriginary state, but it is considered an important stage in Romanesque stylistic evidence and development. ${ }^{3}$ The portal is definitely unlike any extant medieval portal due to its diversity of sculptural hands expressed in divergent stylistic marks that lack cohesion, a variety of material stone types, ${ }^{4}$ and many broken and discontinuous pieces placed side by side. While the whole portal is not the subject of this article, it sets the stage for the contextualization of the figure from this same portal which is of interest to the present volume, whose origin is a session at the Medieval International Congress at Leeds in 2015 on ambiguous women. ${ }^{5}$ Here, the ambiguous woman is the Woman with the Skull (Fig. 2) located in the leftmost tympanum of this portal. The ambiguity of the south portal of Santiago de Compostela remains problematic because it has been the focus of singular identity studies that funnel into investigations that trace how these identities have many categories orchestrating the meaning. Perhaps, the lack of meaning on the south portal perceived by some is based on the expectation of conceptual priority for medieval portal creation which plays an extremely important role as a counterpoint in interpreting the portal and the Woman. Ambiguity depends on lack of knowledge about something that separates universals and particulars and subsequent conflation of many universals into one particular (ability to fit into more than one category) or suppression of many particulars into one universal (stereotyping). ${ }^{6}$ Putting the universal and particular at an intersection to one another usually implies one force as active and the other as passive.

\footnotetext{
${ }^{3}$ M. F. Hearn, Romanesque Sculpture, 148. Hearn ascribes a development in the school of the Languedoc to the south portal.

${ }^{4}$ For diagrams noting where the various materials appear in the portal, see J. M. Cabrera, I. Seara, and J. de Miguel, "Portada de las Platerías: Catedral de Santiago de Compostela," Ars sacra, 38 (2006): 22-37, esp. 34.

5 International Medieval Congress, Leeds, 2015, "Ambiguous Women in Medieval Art," Sessions 1503 and 1603, https://imc.leeds.ac.uk/dbsq102/AQueryServlet?* context $=$ IMC\&*id=10\&*formId $=1$ $\& *$ request Type $=$ query\&conference $=2015 \& *$ servletURI $=$ https $: / /$ imc.leeds.ac.uk $/ \mathrm{dbsql}$ 02/AQueryServlet (accessed September 29, 2017).

${ }^{6}$ The etymology of the word 'ambiguity' ultimately comes from the Latin word ambigere meaning 'to wander.' The mobility of the sculptures on the south portal further underscores this definition in their unfixed histories. "Ambiguous," The Online Etymology Dictionary, http://www.etymonline.com/index.php?term=ambiguous (accessed 29.09.2017).
} 
In the case of the Woman with the Skull, there is a tendency to attempt to condense her down to one identity with symbolic potentialities towards many universals. This is the case with Rückert's analysis which sees her as Bathsheba extending to general categories of physical attributes like Eve and meaning like Ecclesia. ${ }^{7}$ Others see her as a general category related to the chansons de geste like Williams does. ${ }^{8}$ Castiñeiras sees the woman as a vacuous vice that directs its message to the vows of priests ${ }^{9}$ and Sastre sees her as a moniker of legal marriage commitments. ${ }^{10}$ While Mathews vaguely hazards the Woman's identity to Queen Urraca, daughter of Alfonso VI, valid objections can be voiced about the historical identity of the Woman that would produce a shaming of such high authority. ${ }^{11}$ However, by blurring the lines of identity to many historical personages, the ambiguity of this shaming might make the statement cloaked from potential objection. This study introduces a different tactic to its predecessors by seeing multiple historical identities as conflated into the universal symbol.

\section{The Woman with the Skull}

In the case of the current state of the Woman with the Skull located in the right corner of the leftmost tympanum of the two tympana of the south portal of Santiago de Compostela, her physical state is one where her material has been forcefully cut in a way that compromises the pre-

${ }^{7}$ Claudia Rückert, "A Reconsideration of the Woman with the Skull on the Puerta de las Platerías of Santiago de Compostela Cathedral,” Gesta 51/2 (September 2012): 129 146, esp. 134 and 140,

http:/ /www.journals.uchicago.edu.pitt.idm.oclc.org/toc/ges/2012/51/2 (accessed 29.09.2017).

8 John Williams, "La Mujer del cráneo y la simbología románica," Quintana 2 (2003): 13 -28 , esp. $20-21$

9 Manuel A. Castiñeiras González, "Arte románico y reforma eclesiástica," Las religiones en la historia de Galicia. 7 - 8 (1996), 307 - 332, esp. 317,

http://dspace.usc.es/handle/10347/4735 (accessed 29.09.2017).

10 Carlos Sastre Vázquez, "La Portada de las Platerías y la "mujer adúltera": una revisión," Archivo español de Arte, 79/314 (2006), 169 - 186, http://xn-archivoespaoldearte-53b.revistas.csic.es/index.php/aea/issue/view/2

(accessed 29.09.2017).

${ }^{11}$ Karen Rose Mathews, "They wished to destroy the temple of God": Responses to Diego Gelmírez's cathedral construction in Santiago de Compostela, 1100 - 1140." (PhD diss., The University of Chicago, December 1995), 204 - 206, accessed 29.09.2017, ProQuest Dissertations \& Theses. 
established lines of her representation to fit the space. ${ }^{12}$ This suggests that the material representation existed prior to the new program or concept for the portal and then was physically manipulated to fit the new idea. In turn, this is a concept that forcefully converts a material entity.

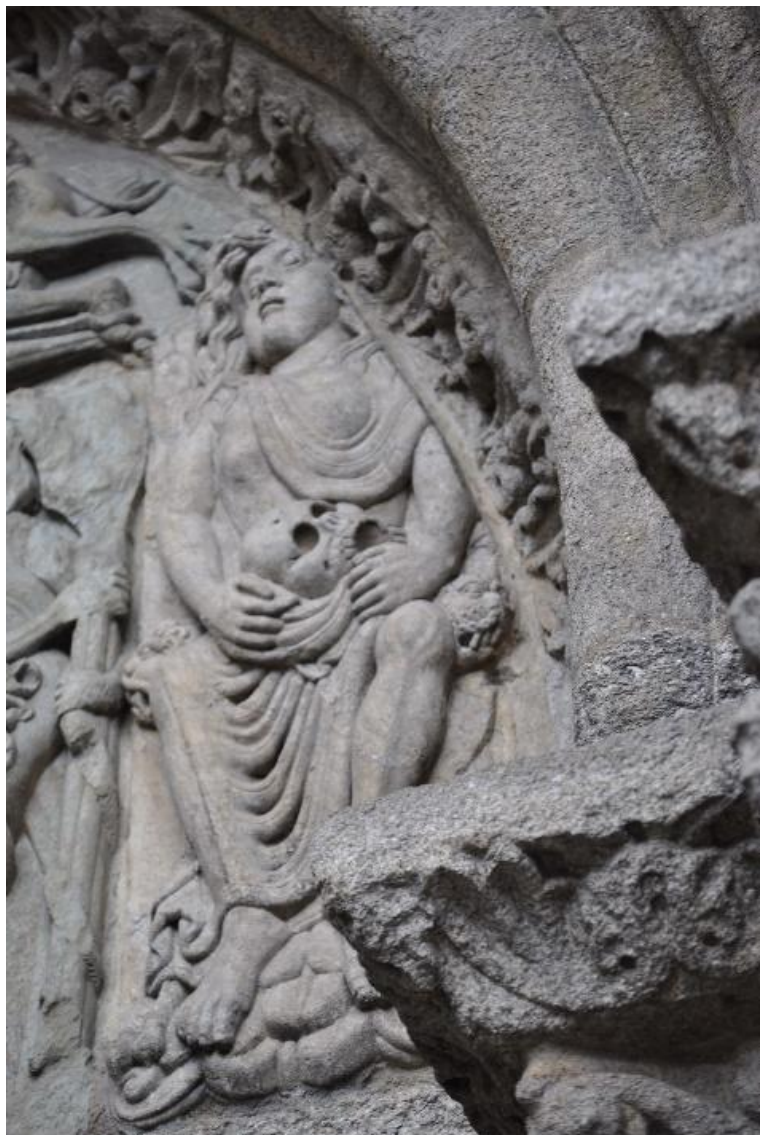

Fig. 2. Woman with the Skull (photo: the author)

12 Sastre, "La Portada de las Platerías," 169, Lyman speaks of the isolation of the woman. Thomas W. Lyman, "Motif et narratif: vers une typologie des thèmes profans sur la sculpture monumentale sur la romanias," Les cabiers de St. Michel-de-Cuxa, 10 (1979): $59-79$, esp. 66. 
The Woman with the Skull suffers from the same fate as the portal due to its singular iconography and one secluded interpretation from the Pilgrim's Guide. While the Pilgrim's Guide states that the woman is adulterous and is forced by her vengeful husband to kiss the decapitated head of her deceased lover twice a day, Williams and Lyman consider her an exemplum. ${ }^{13}$ As an exemplum, she is a cautionary tale, which suggests comparison, but this essay argues that, more so, she is a tool of superimposition applied to the historical lives of women. The Guide's interpretation directs a pointed attempt to use categorization towards the ends of systemic misogynistic abuses. Her subjection to a specific identity that becomes categorical in the scholarship has obscured her suffering enabled by the Pilgrim's Guide by making the individual into a category forced upon women like the location of the tympanum was forced upon her. ${ }^{14}$ Azcarate's concern with the moral import of the woman as an example of types of vices like Luxuria, would seem to initially imply that she is nameless. ${ }^{15}$ However, because many women in Christian tradition can fit into this category based on narrative biases and stereotypes, the Woman

13 "Nor should be forgotten the woman who stands next to the Lord's Temptation, holding between her own hands the stinking head of her lover, cut off by her rightful husband, which she is forced by her husband to kiss twice a day. Oh, what ingenious and admirable punishment for an adulterous wife; it should be recounted to everyone!" [Nec est obliuioni tradendum, quod mulier quedam iuxta dominicam temptacionem stat, tenens inter manus suas caput lecatoris sui fetidum, a marito proprio abscisum, osculans illut bis per diem, coacta á uiro suo. O quam ingentem et admirabilem iusticiam mulieris adulterate omnibus narrandam!]" The Pilgrim's Guide is estimated as dating to around 1130. Gerson, Shaver-Crandell, Stones, and Krochalis, ed. and trans., The Pilgrim's Guide, Vol. II: The Text, Chapter IX, 74 - 77, According to Stefan Trinks, as early as 1976, Williams identified the Woman as exemplum libidinis. Stefan Trinks, "Sheela-na-gig Again: The Birth of a New Style from the Spirit of Pornography," in Pornographic Art and the Aesthetics of Pornography (London: Palgrave Macmillian, 2013), 162 - 182, esp. 179, ftnt 16. Later discussion of the exemplum libidinis by Williams is found in 2003. Williams, "La Mujer del cráneo," 20 -21. Azcarate equates the woman with representations of the vice, Luxuria, shown with serpents biting her breasts. José María de Azcárate, "La portada de las platerías y el programa iconográfico de la catedral de Santiago," Archivo español de arte, 36 (1963): 1 - 20, esp. 10. Lyman considers the woman a testament to the profane and the hierarchical. Lyman, "Motif et narratif," 66.

${ }^{14}$ Lyman and Sastre are the starting point for this line of thinking. Lyman suggests the generally profane nature of the woman in addition to her isolation. Lyman "Motif et narratif ," 66, and Sastre emphasizes her mutilation. Sastre, "La Portada de las Platerías," 169.

15 Azcárate, "La portada de las platerías," 10. 
becomes the source of much debate. But, while invigorating, the debate largely remains on the periphery of the problem the Woman poses.

The verification of the Woman with the Skull's identity has long been dependent on words. The Woman's singularity led Walter Cahn to state that there are no visual iconographic parallels to the Woman with the Skull, seeming to make verbal transmission the only possible lead. ${ }^{16}$ Though comparisons have been made to the Signs Relief from St. Sernin in Toulouse which features two women, one with a ram in her lap and one with a lion in her lap, neither holds a human skull. ${ }^{17}$ In spite of this lacuna, the stone on which the women are carved is inscribed to indicate that the women allude to the zodiac signs: the sign of Aries and sign of Leo. Though Aries is related to the ram, in the heretical philosophy of the Zodiac Man, the sign of Aries is also the sign that is identified with the human head. ${ }^{18}$ By seeing the ram as a symbolic sign and the head as a literal meaning, the two images are superimposable. This superpositioning can be further supported because the Woman with the Skull is also accompanied by another work on the south portal called the Woman with the Lion Cub. The idea that visual parallels carry a heretical implication is not difficult to imagine. An identity being superpositioned over another is a magical and dangerous prospect. In fact, as the Investiture Conflict is a topic in this study, one of its defining issues, the whole problem with simony or the selling of working historical or 'counted' identities of ecclesiastical presence to secular identifying presences, has a correlation to this identity projection. Similarly, the problem of consanguinity as many

\footnotetext{
16 Walter Cahn, "Romanesque Sculpture and the Spectator," The Romanesque Frieze and its Spectator: The Lincoln Symposium Papers, ed. Deborah Kahn (London: Harvey Miller Publishers, 1992), 45 - 60, esp. 59 - 60.

17 Elizabeth Valdez del Álamo states that the Signs Relief and Woman with the Skull are generally connected by iconography like the general meaning of goddess figures like the mother goddess with lion or Aphrodite with a ram. No causal relationship is explicated between the Signs Relief and the women at Santiago. See "Cat. 86: Relief of Two Women with a Lion and a Ram," in Art of Medieval Spain, AD $500-1200$ (New York: The Metropolitan Museum of Art, 1993), 206.

18 Orosius details the Zodiac Man in his descriptions of the heretical Priscillians' beliefs. Orosius, Commonitorium Orosii et Sancti Avrelii Augustini contra Priscillianistas et Origenistas, ed. Klaus-D. Daur, CChr XLIX (Turnholt: Brepols, 1985), 159. “[Priscillian] . . . [c]ontra autem in membris corporis caeli signa esse disposita, id est arietem in capite, taurum in ceurice, geminos in bracchiis, cancrum in pectore, et cetera ..."
} 
reproductive or symbolically consuming roles taken on by one person is the inverse problem as is discussed below.

\section{The Investiture Controversy}

The connection between symbolic category and historical personage in a comparative stance or as stratified layers need to be interchangeably considered. Royal authorities attempt to make the temporal role comprehensive and multi-categorical that can clothe one in leadership dependent on the fragmenting of the material or genetic integrity of the person's natal role. The pope needed to preserve the 'whole' material body as an integrated role for the fragmented temporal/historical individual. The very nature of the portal and the condition of specifically the Woman with the Skull relates to the constantly evolving conflict between royal and papal forces in the eleventh century. The issue of investiture relays transitions from the belief in the gladius spiritualis and gladius temporalis (the spiritual and temporal swords) and the gladius spiritualis and gladius materialis (the spiritual and material swords). ${ }^{19}$ The portal as a material accumulation with its diversity of stones and temporal performance displaces and reintegrates the northern sculpture to the south suggests these two sets of swords.

While the investiture conflict resulted in a dispute about whether the material and temporal could be usurped by the pope, the purpose of this study is to examine the different implications of material like the control over capital punishment or as a consanguinity dispute. ${ }^{20}$ These demarcations relate to the royal compulsion which separates the symbolic blood of the royalty from the historical blood of the lay population and papal authority which superimposes universal morality over particular material. The drive to maintain a symbolic structure for the royalty means material isolation from historical genetics. The Signs Relief is important at this juncture because of the interspecies implications of the women giving birth to animals.

${ }^{19}$ For a list of citations on the gladius spiritualis, gladius materialis, and gladius temporalis, see Carra Ferguson O'Meara, The Iconography of the Façade of St. Gilles-du-Gard (New York: Garland Publishing, 1977), 172 - 173, ftnt 88.

${ }^{20}$ Gerhart Ladner, "The Concepts of "Ecclesia" and "Christianitas" and their Relation to the Idea of Papal "Plenitudo Potestatis" from Gregory VII to Boniface VIII," in Miscellanea Historiae Pontificiae, Vol. XVIII, ed. Facultate Historiae Ecclesiasticae in Pontificia Universitate Gregoriana (Rome, 1954), 49 - 77, esp. 58. 


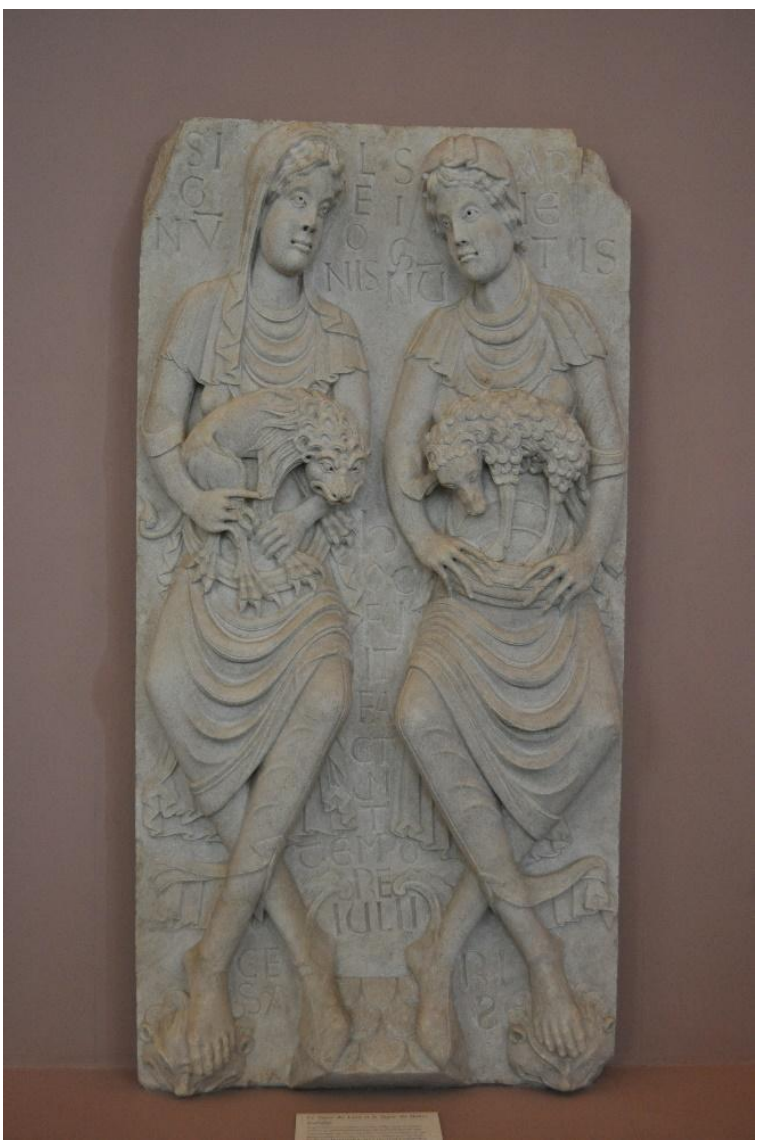

Fig. 3. Signs Relief, Musée des Augustins, Toulouse, France (photo: the author)

The notion of cross-species procreation is suggested in the inscription which states "Signum Leonis, Signum Arietis; Hoc fuit factum tempore Iulii Cesaris. ${ }^{21}$ The texts which have similarities to the sculpture states that the two women are the signs of the lion and the ram which take place in the time of Julius Caesar. ${ }^{22}$

21 'SI/G/NV[M]/L/E/O/NIS//S/I/G/NU[M]//ARI/E/TIS/H/

$\mathrm{OC} / \mathrm{FU} / \mathrm{IT} / \mathrm{FA} / \mathrm{CT} / \mathrm{UM} / \mathrm{T} / \mathrm{TEMPO} / \mathrm{RE} / \mathrm{IULII} / / \mathrm{CE} / \mathrm{SA} / /$

$\mathrm{RI} / \mathrm{S}$

22 Bede connects July or Julii to Julius Caesar. Mora suggests that the cold and hot temperatures of March and July are part of the meaning of the plaque. Mora, "Signum 
The symbolic (cross-species birth) and historical (Julius Caesar) are interwoven here. The moral transgression of copulating with nonChristian parties much less animals was a rule that is morally prohibitive but not physically impossible. The inability to categorize the otherworldly and its mixing with the human suggests the inapplicable rules of human morality to animals and the otherworldly. In this perspective of God as another category of being, God does not have to abide by these internal rules. Meanwhile, the papal morality demands that species, categories, or symbolisms not mix, but like subjects can. This arrangement establishes strict procreation-based rules. ${ }^{23}$ The similarity of the Woman with Skull and her counterpart on the south portal, the Woman with the Lion Cub, to Toulouse's Signs Relief (Fig. 3) cannot be ignored. ${ }^{24}$ In the sign of Aries and the sign of Leo, the two zodiac signs are different categories but they share the same material substance of fire from among the four elements used in astrological rules. ${ }^{25}$ Could the likeness of material or substance relate to the birth of

Leonis, Signum Arietis," Mora, Bernadette. "Signum Leonis, Signum Arietis." Annales du Midi: revue archéologique, historique, et philologique de la France méridionale 103/196 (1991): 483 - 489, see esp. 485, 488, http://www.persee.fr/doc/anami_00034398_1991_num_103_196_7611 (accessed 19.11.2017). Bede, Manfredi Carmina, PL 94, col. 642-644.

${ }^{23}$ Durliat indicates that orally-transmitted legends that indicate two virgins gave birth, one to a lion cub and the other to a baby ram, in the time of Julius Caesar, and relates to the Last Judgment. Because this legend cannot be verified, Durliat sides with his colleague, Jean Soubiran, who Durliat publishes as simply seeing the ' $T$ ' in the inscription as indicating 'in' the time of Julius Caesar and relating the signs to the zodiac. Marcel Durliat, La sculpture romane de la route de Saint-Jacques (Mont-de-Marsan: Comité d'Études sur l'Histoire et l'Art de la Gascogne, 1990), 414 - 415. In the story of a young girl who has lost her virginity, this girl, Mary, is reclaimed by her uncle dressed as her lover. Hrosvit calls this cloaking of the personality of the uncle as instead a lover of his niece as 'sub specie amoris.' The significance carried by imitation of a body, gesture, or mannerism in the Cathedral Schools means that 'imitating' a lover of a relative retained some incestuous carriage from the putting on of the disguise. Being 'under a zodiac sign' like being under any classification or incest-determined category has larger implications of retaining the category's 'character.' Hrosvit of Gandersheim, Hrotsvit: Opera Omnia. Ed. Walter Berschin. (Muenchen: K. G. Saur, 2001), 195.

24 Valdez del Álamo, "Cat. 86: Relief of Two Women with a Lion and a Ram," 205 206.

25 In the West, thinkers like William of Conches mention the substances of the zodiac signs, though in a pejorative way. The Arabic influences in Spain would mean more plentiful sources in Spain. William of Conches (Guillelmus de Conchis), Dragmaticon Philosophiae, Turnhout: Brepols, 2001, Book III, 7, v, 77. This is also available in English 
Alfonso VII whose rulership is announced in an inscription on the upper wall of the portal? ${ }^{26}$

The concept of a changing identity or a changing meaning marks equal potential for Christian officials as positive or negative. The idea that the sign of Aries as a ram or a human head is a symbol or changeable, but its meaning is the same is related to substitutable templates. When this template is internally connected to Christianity, it relates to symbolic adoption of orthodox conversion, but when it is externally imposed from other religions, it relates to apostasy. The many meanings of a lion who relates to Jesus as Christ and becomes associated with Satan, produces the potential for a historical identity that in lifestyle becomes external by aligning with the external practices of Christianity contrasts with the perceived reliance on internal frailties of temptation dominating external actions. ${ }^{27}$ Thus, the internal conversion and the external lifestyle mark a 'good' Christian. For this internal conversion, the guided will of the individual and the lifestyle emulation are key. While the pope needs the internal will to be guided in choice, the royal needs the internal material to be determined

in A Dialogue on Natural Philosophy (Dragmaticon philosophiae), ed and trans. Italo Ronca and Matthew Curr (Notre Dame: University of Notre Dame Press, 1997), 52 - 53.

26 The inscription is ANF REX. The traditional usage of this inscription in the dating of the portal can be considered as a flexible marker. Næsgaard indicates that it can be no earlier than 1109 when Alfonso VI died. Ole Næsgaard, Saint-Jacques de Compostelle et les débuts de la grande sculpture vers 1100 (Aarhus: Universitetsforlag, 1962), 9. There is potential to investigate this inscription as possibly related to the date of the coronation of Alfonso VII, but also the wave of support for Alfonso VII in Santiago during Queen Urraca's reign in a movement supporting her son over the queen in a social organization called Raimundism. This movement was particularly strong in the west of Spain. Bernard F. Reilly, The Kingdom of León-Castilla under Queen Urraca: 1109 - 1126 (Princeton: Princeton University Press, 1982), 78.

27 The medieval bestiary interprets the birth of the lion as related to resurrection like that believed of Jesus. Richard Barber, Bestiary: being an English version of the Bodleian Library Oxford MS Bodley 764: with all the original miniatures reproduced in facsimile (Woodbridge: Boydell Press, 1992), 24 - 25. Some of these basic ideas are found in Isidore. Isidorus Hispalensis, Etymologiae, PL, 82, 434c - 434d. accessed 30.09.2017; Etymologies of Isidore of Seville, trans. Stephen A. Barney, W. J. Lewis, and J. A. Beach (Cambridge: Cambridge University Press, 2006), Book 12, 2: 3 - 6. Meanwhile, in 1 Peter 5: 8, it states "Be sober and watch: because your adversary the devil, as a roaring lion, goeth about seeking whom he may devour." The Holy Bible (Donay Rheims Version) (Rockford: Tan Publishers, 1899), 267. 
without choice through marriage. ${ }^{28}$ In turn, while the pope needs the external material body to emulate the religious ways of Christianity, the royal needs the conceptual body to accumulate many meanings through consanguinity-violating roles. This means that the material body takes on many conceptual roles of family like the adoption of many familial roles on the arbor consanguinitatis. Thus, for royal purposes, the material needs to adapt and occupy many constructed temporal roles (wife, sister, and daughter in one person) according to the situation. For the papacy, the material needs to be strictly emulative of the larger construct or be ostracized.

Symbols are inhabitable spaces or contexts, and the defining difference between the royal uses of conceptual genealogies as collapsible symbols and the papal use of the material as shapeable orients the discussion towards the story of Adam and Eve. The emphasis on the Original Sin in the south portal's imagery due to the north portal sculptural displacement establishes the senses ascribed to Adam in Genesis as the primary verbal actor in the Genesis story as materially subtracted like the north portal. ${ }^{29}$ Eve, who is conceptually imagined prior to her birth and then made from Adam's rib - a

\footnotetext{
28 Although discussing France, Duby explains that the late eleventh and early twelfth centuries was a time in which lineage structures tightened in a way that resulted in internecine cleavage among family members who were seniors and those that had less of a chance at patrimonial authority. The current article views Alfonso VI's penchant for incestuous and power-based relationships as related to his driven need for blood-based succession, even if that meant resorting to incest. Georges Duby, Medieval Marriage: Two Models from Twelfth-Century France, trans. Elbord Forster (Baltimore: John Hopkins University Press, 1978), 7 - 15.

${ }^{29}$ Jaeger aligns the idea of clay being shaped (here, on the potter's wheel) with the idea of context acting upon the forces of individual emulation like hands that shape the clay. This is related later in the current discussion for how contextual sound shapes the individual from without. For Latin texts like that of Goswin (Gozechinus), Epist ad Walcherum, PL 143, 885 - 908, or Apologiae Duae: Gozechini epistola ad Walcherum; Burchardi ---apologia de barbis, ed. R. B. C. Huygens, intro Gilles Constable, CCCM 62 (Turnhout: Brepols, 1985), 11 - 43. For English translation, see C. Stephen Jaeger, "Appendix B: The Letter of Goswin of Mainz to his Student Walcher (ca. 1065)," in The Envy of Angels: Cathedral Schools and Social Ideals in Medieval Europe, 950 - 1200 (Philadelphia: University of Pennsylvania Press, 1994), 349 - 375, specifically, chapter XXVII, 32, 366 (lines 627 - 635). For Jaeger's commentary on the potter's wheel and clay, see Jaeger, The Envy of Angels, 3, 8, 223, $372-373$.
} 
fragment, may represent the south portal. ${ }^{30}$ The lack of material emulation in the entire portal's comparison to other Romanesque portals provides a potential for the portal as relating not to universals being condensed into a particular example (like Rückert's view of Bathesheba), but particulars being condensed into a universal (many historical bodies made to function in one role). In the Genesis story, Eve was silent in speech before the serpent tempts her, but then she acts as agent of speech which was formerly Adam's role. Adam, who speaks, takes on the visual imitation by following Eve's actions. While Rückert's view of the Woman with the Skull as Bathesheba is not incorrect, it leads her from one particular to many universal attributions like Ecclesia and substitutional appearance like that of Eve. ${ }^{31}$ The typical juxtapositioning of Ecclesia in relationship to the blind Synagoga marks the differences between Adam and Eve before original sin. Though never suggested, Ecclesia is not blindfolded and assumedly sight-enabled, but the inversion of blindness in Synagoga who can hear, can be related to a possibility that Ecclesia is unrepresentatively deaf. ${ }^{32}$ In Christian interpretations of the roles of Synagoga/Adam and Ecclesia/Eve before Original Sin were cooperative and interdependent. Like the pope's emphasis on material or visual emulation and the royals' emphasis on temporal or conceptual accumulation like hearing make the Investiture Controversy even more relevant.

The papal interest in consanguinity suggests the papal context in which the conclusion of the text as a restricted reproduction found only in a papal document like the Codex Calixtinus points to a papal polemic. The slant of the Woman's relationship to adultery is the focus of Sastre's marriage argument which participates in the practice of an 'orthodox' remedy to Original Sin. Though Sastre takes up the issue of

\footnotetext{
30 Again, due to restrictions of space, potential conceptual orderings of the south portal cannot be taken up in this essay.

31 Rückert, "A Reconsideration," 134, 140.

32 There is more to be said on this matter. The seemingly problematic evidence of the Pseudo-Augustine's tract on the disputation of Ecclesia and Synagoga that requires verbal exchange might lead to questions about this assumption; however, moving towards a fuller understanding of this issue, the subject will be addressed by this author at the $52^{\text {nd }}$ International Congress on Medieval Studies at Western Michigan University, Kalamazoo in a session entitled: "Negativity and Emptiness in the Intellectual Culture of the Middle Ages" hosted by the Claremont Consortium for Medieval and Early Modern Studies."
} 
the 'adulterous' label of the Woman and her seating on a faldistorium, he does not mention the idiosyncrasies between the visual image of the woman as seated and the Pilgrim's Guide which says she is standing. ${ }^{33}$ If she is seated, her body spans more than one consanguineous zone on the stair step shape of her body and the arbor consanguinitatis (consanguinity tree/table, Fig. 4). By insisting in the text of the guide that she is standing, the prevention of the consanguineous trespass among zones is accomplished by it not being spanned.

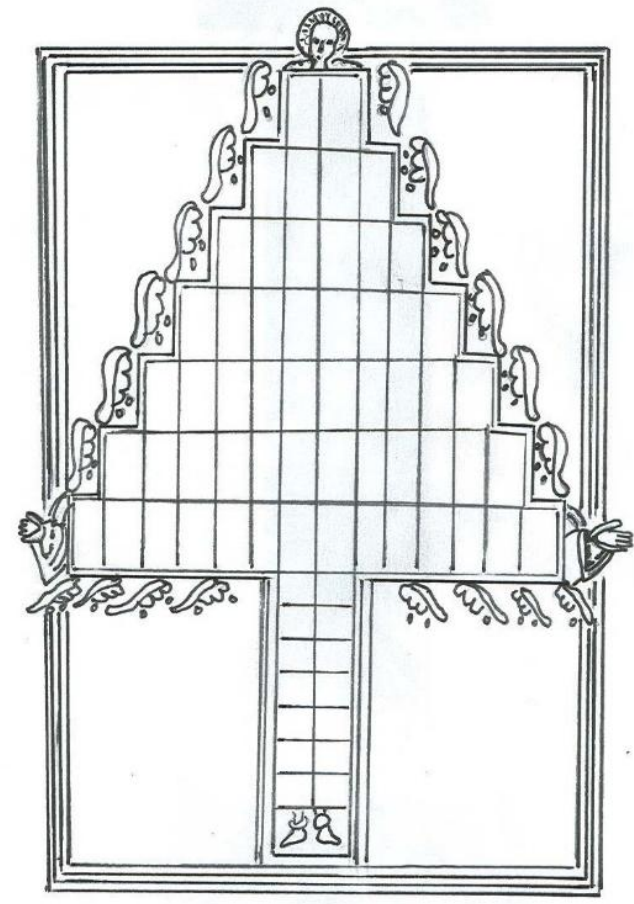

Fig. 4. Consanguinity Tree from Isidore of Seville's Etymologies (Madrid, Real.

Acad. De la Hist., MS 76, fol 73v, 10th century, for original, see http://bibliotecadigital.rah.es/dgbrah/i18n/consulta/busqueda.cmd)

33 “. . . the woman who stands next to the Lord's Temptation, " [“. . . quod mulier quedam iuxta dominicam temptacionem stat . . .’], Gerson, Shaver-Crandell, Stones, and Krochalis, The Pilgrim's Guide, Vol. II, 74 - 75. For footnotes that indicate this difference between text and image, Rückert, ibid. 207, ftnt 84; Sastre Vázquez, "La Portada de las Platerías," 172 , 184. 
The study of posture as indicative of character has a long history in the Middle Ages. The celebration of masters of cathedral schools whom students were encouraged to externally clone in their comportment mark the idea of external boundaries of the body as meaning laden. 34 This further underscores the body posture's relationship to a diagram. In fact, in many of the texts concerning the character of the scholar, their 'ornament' is determinative. ${ }^{35}$ In terms of the Woman with the Skull, the alignment of the drapery and body can be compared to diagrams of science and linguistics to suggest the relationship of the Woman to constructs of nature and morality. ${ }^{36}$

The Woman with the Skull's drapery uses an ' $\mathrm{X}$ '-shape to partially and shamefully hide her nudity. This essay pursues the ' $\mathrm{X}$ '-shape as related to the Wheel of Fortune or a diagram of royalty, here, used to cover the body. The idea of Original Sin as related to sense-based role adoption (seeing or hearing/speaking in Eden) inevitably relates the Fall of Man to semiotics. By seeing the language-tainted body of the Woman examined here as Original Sin, the diagrams of the Square of Opposition and the Wheel of Fortune provide opposing traditions that relate to the Investiture Controversy between royal objectives and papal objectives. As seen below, the tyranny of language in orthodox Christianity (and medieval art historical discourse) impacts generalized constructs of language's exercise of power over the body is seen as controlled by papal jurisdiction.

\footnotetext{
${ }^{34}$ For an overview of the entire work's argument about the charismatic culture that resulted in physical emulation, see Jaeger, The Envy of Angels, 7 - 14.

35 One example from Jaeger is the Würzburg poem. Elizabeth Häfner, Die Wormser Briefsammlung des 11. Jahrbunderts, Erlanger Abhandlungen zur mittleren und neueren Geschichte 22. ed. Walthur Bulst. (Erlangen: Palm and Enke, 1935), 119 - 21.

36 Ornatus has connections to the creative act in relationship to the material or elemental. Because the process of creation is either imitative of material form/iconography or imitative because of process, the Woman with the Skull's uniqueness in form suggests that her imitation (unlike the scholars who imitate the stature or form of their mentors) has been of material or intra-consanguineous acts. For ornatus, see Brian Stock, Myth and Science in the Twelfth Century: A Study of Bernard Silvestris (Princeton: Princeton University Press, 1972), 126.
} 


\section{The Temporal and Material Sciences. The Temporal and Spiritual Languages}

The differences between the conceptual as language and the material as science are best illustrated in discussions of the linguistic diagram of the Square of Opposition (Fig. 5) and the science-based diagram of the Wheel of Fortune (Fig. 7). Before introducing the history of the diagrams, a cursory look at the diagrams implies the empirical nature of the Wheel of Fortune and construct-based control of the Square of Opposition. The royal figure who falls and rises according to the turning wheel's gravity and friction of what any human learns through experience about the human environment suggests contextual awareness. The constructs of language in the Square of Opposition suggest a systematic set of rules to be emulated. The translation of material inevitability that mixes history and symbolism is attempted to be forestalled by royal intermarriage while the application of conceptual rules to the physical body is part of the papal project of conversion. The nature of language becoming integrated with the body is inherent in the Genesis story.

The Square of Opposition (Fig. 5) is a diagram historicallydeveloped in Aristotle's tract On Interpretation and On Categories, which was not prevalent until 1266 by William of Moerbeke who made a Latin translation of Simplicius' commentary on the latter text. ${ }^{37}$ This version enabled Thomas Aquinas to be the initial commentator on Simplicius, followed by Siger of Brabant (thirteenth century), Henry of Ghent, Giles of Rome, and Godefroid de Fontaine. ${ }^{38}$ While this may seem too late for Santiago's portal, Spain had access to Arabic translations and beginning as early as the tenth century, the ideas of Simplicius were known in Arabic texts. ${ }^{39}$ The works of the great Islamic scholar, Abu Naṣr Muḥammad ibn Muḥammad ibn Ṭarkhan ibn Awzalugh al-Fārābī (d. 991) have been assessed to have connections with Simplicius although not stated directly by him in his works with their vast

\footnotetext{
${ }^{37}$ Michael Chase, "The Medieval Posterity of Simplicius' Commentary on the Categories: Thomas Aquinas and Al-Fārābī," in Medieval Commentaries on Aristotle's Categories, ed. Lloyd A. Newton. (Leiden: Brill, 2008), 9-29, esp. 9. Simplicius wrote his commentary in $538 \mathrm{CE}$.

38 Ibid., 9-11.

${ }^{39}$ Ibid., 11-12. The Arabic manuscript most readily available to a western audience is Paris, BN ar. 2346 prepared by al-Ḥasan ibn Suwār.
} 
intellectual content. Evidence such as similar teaching styles and other medieval writers like Averroes (1126 - 1198), who also uses Simplicius without citing him, led scholars towards the conclusion that Categories was available to Arabic writers. ${ }^{40} \mathrm{Al}-\mathrm{F}$ àrābi states that the status of the soul as intelligible, means that it possesses no separation in its perception of subject and object, making language unneeded until the soul becomes embodied, requiring vision and sound to understand. ${ }^{41}$ While Adam and Eve divide these responsibilities to act as 'two of one flesh,' their expansion to many roles in Eden results in their separation of identity and the realization of an imbalanced relationship between subjecthood and its opposite objecthood.

The diagrams of the Square of Opposition (Fig. 5) and the Wheel of Fortune (Fig. 6) have similarities to the Romanesque diagram of Hugh of Fouilloy's Wheels of True and False Religion ${ }^{42}$. The Wheel of True Religion features two upright figures on either side of a static wheel. In the Square there are different subjects at the top but the same predicates throughout. Also, in the Square, there is a designation of contradictions on the diagonal which also applies to the True Religion wheel in the different body parts of the head and the feet of the two figures being on the diagonal. In the Wheel of True Religion, the two figures are holding between them a static wheel. It might seem coincidental that the two diagrams correspond if it were not for Hugh's other diagram of the Wheel of False Religion.

\footnotetext{
40 Phillippe Vallat, Farabi et l'école d'Alexandrie: Des prémisses de la conaissance à la philosophie politique (Paris: Librairie Philosophique J. Vrin, 2004), 172-173. Chase, “The Medieval Posterity of Simplicius' Commentary on the Categories," 12, 17-18.

${ }^{41}$ Chase, "The Medieval Posterity of Simplicius' Commentary on the Categories," 18.

42 The Medieval Book of Birds Hugh of Fouilloy's Aviarium, ed. and trans. Willene B. Clark, (Binghamton: Medieval \& Renaissance Texts \& Studies, 1992), Fig. 48 (Wheel of True Religion, St. Omer, Bibl Mun 94, fol 37v), 52b (Wheel of True Religion, Brussels, Bibl Roy II, 1076, fol 82r).
} 


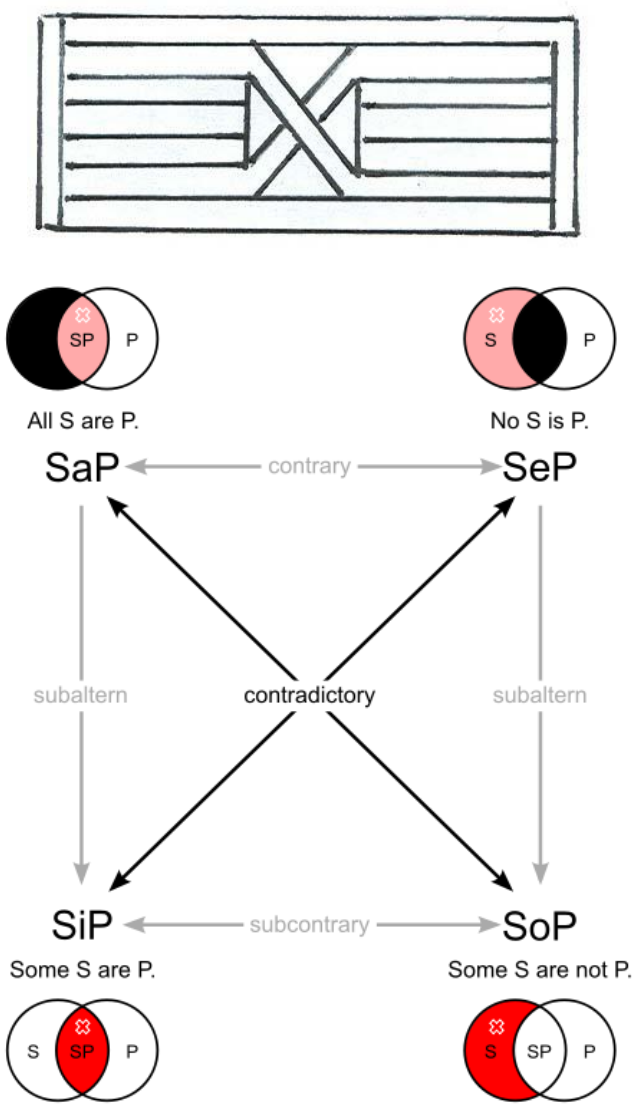

Fig. 5. Square of Opposition from Apuleius' Commentary on Aristotle's Perihermaneias sketched from Philadelphia, Schoenberg Collection MS ljs 101, folio 38r (850 C.E., above, for original, see

http://dla.library.upenn.edu/dla/medren/pageturn.html?q=ljs+101\&id=MED

REN_5186550\&rotation $=0 \&$ currentpage $=81$ ) and below is an explanatory diagram original licensed under Wikipedia Creative Commons and creator Tillman Piesk - Own work, CC BY-SA 3.0, (By Watchduck (a.k.a. Tilman Piesk) - Own work, Public Domain, https://commons.wikimedia.org/w/index.php?curid=15516281) 


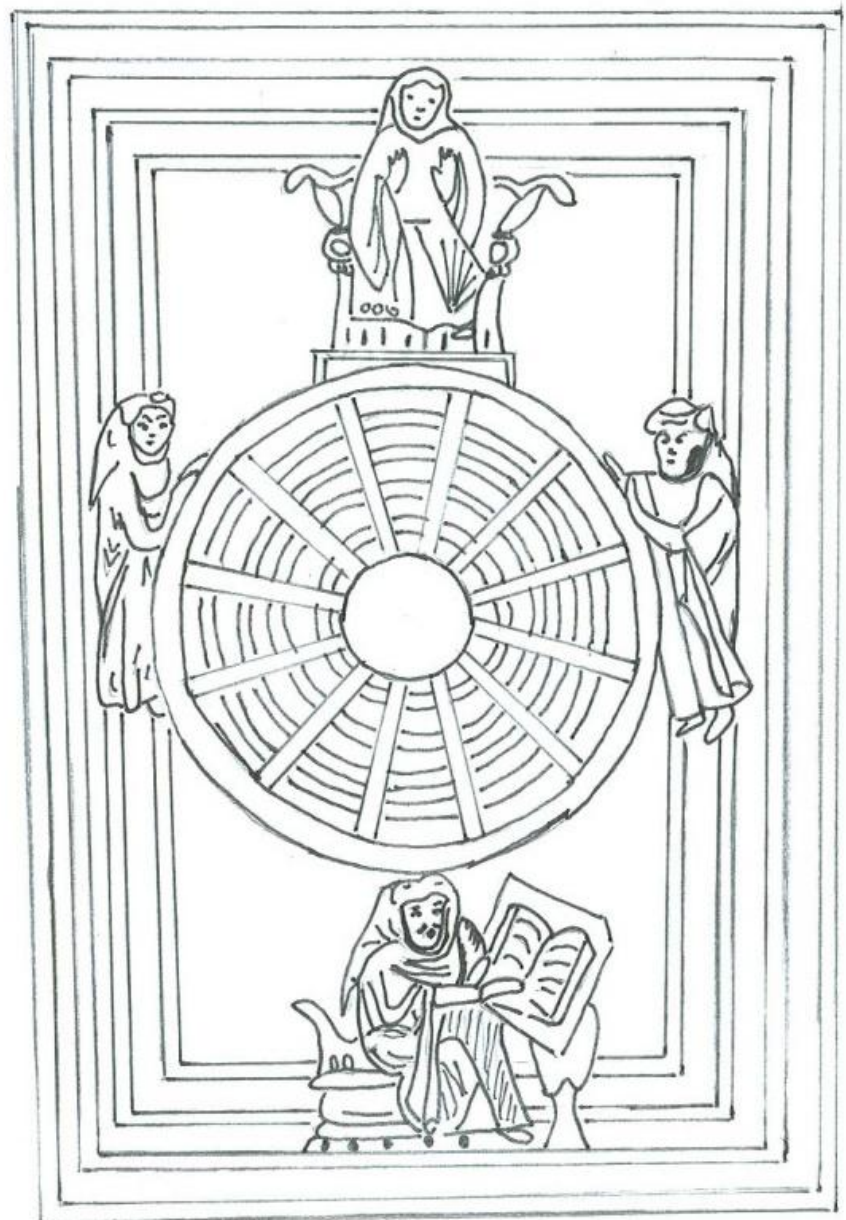

Fig. 6. Wheel of True Religion from Hugh of Fouilloy's De Avibus (Heiligenkreuz, Stiftsbibliothek, MS Cod. 226, fol. 146r, late 12 $2^{\text {th }}$ century, for original see Caviness, "Images of Divine Order and the Third Mode of Seeing," Gesta (p. 114), Fig. 35) 


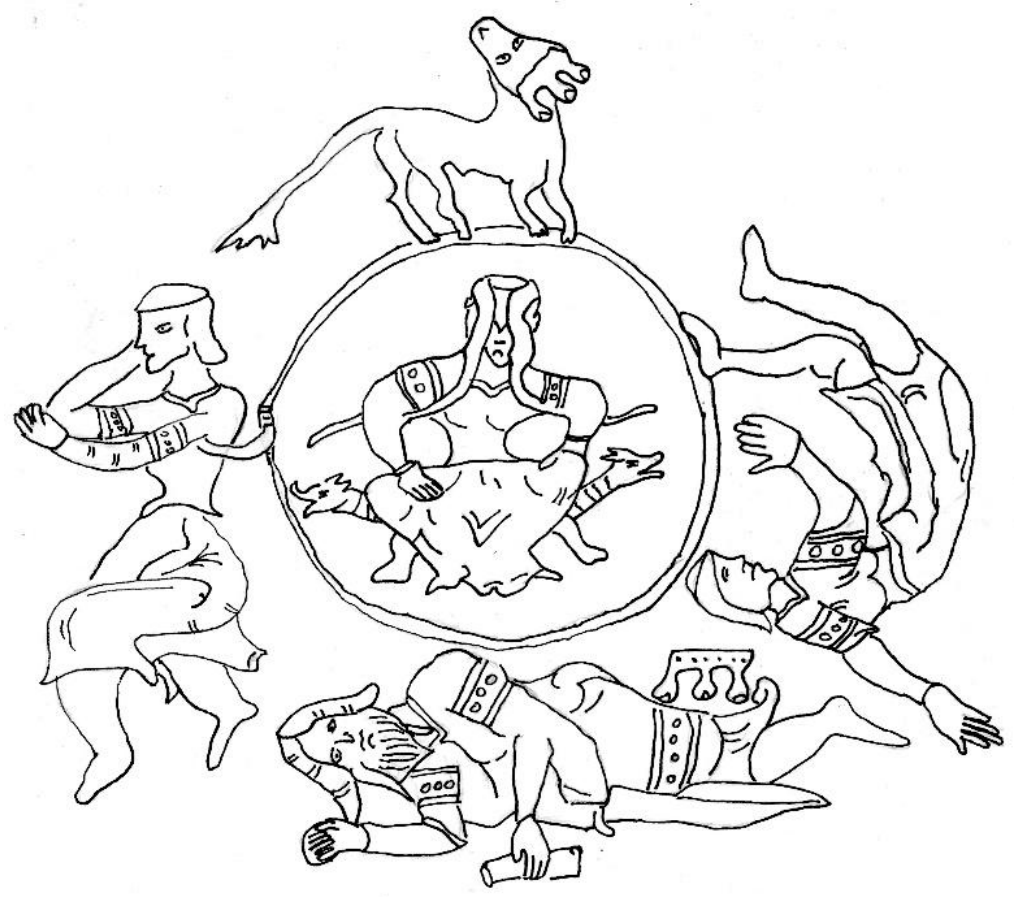

Fig. 7. Wheel of Fortune (Vienna, Österreichesche Nationalbibliothek, MS 2642, fol 11r, 1240-1260, Wheel of Fortune, for original,

http://search.obvsg.at/primo_library/libweb/action/display.do?tabs=details'T $\mathrm{ab \& ct}=$ display $\& \mathrm{fn}=$ search $\&$ doc $=O N B \_$aleph_onb06000162018\&indx $=1 \&$ recIds $=$ ONB_aleph_onb06000162018\&recIdxs $=0 \&$ elementId $=0 \&$ renderMode $=$ poppe dOut\&displayMode $=$ full $\&$ frbrVersion $=\&$ frbg $=\& \& v l(1 \mathrm{UI} 0)=$ contains $\&$ dscnt $=0$ \&scp.scps $=$ scope $\% 3 \mathrm{~A} \% 28 \mathrm{ONB} \_$aleph $\_$hanna $\% 29 \& \mathrm{tb}=\mathrm{t} \& \mathrm{vid}=\mathrm{ONB} \& \operatorname{mode}=\mathrm{Ba}$ sic\&srt $=$ rank\&tab $=$ onb_hanna\&dum $=\operatorname{true\& vl}($ freeText 0$)=2642 \& d s t m p=147956$ 7433382; See no. 25.) 


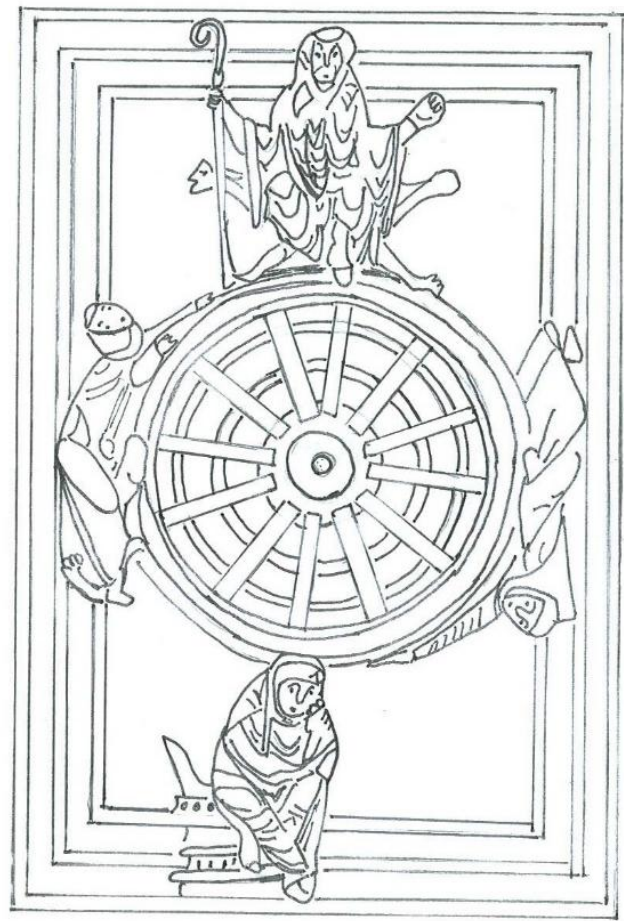

Fig. 8. Wheel of False Religion from Hugh of Fouilloy's De Avibus (Heiligenkreuz, Stiftsbibliothek, MS Cod. 226, fol. 149v, late 12 $2^{\text {th }}$ century; for original see, Caviness, "Images of Divine Order and the Third Mode of Seeing," Gesta (p. 114), Fig. 34)

In the example above, the Wheel of False Religion (Fig. 8) looks like the Wheel of Fortune (Fig. 7) with two inverted figures on either side of the wheel, the mirror left figure is right side up and the mirror right figure is upside down. The Wheel of Fortune features a king who is moving up the wheel to be crowned and then falling off the wheel to lose his crown. The idea that True and False Religion labels are attached to these figures corresponds to the reading of the Square as papal (the spiritual and the temporal) and the Fortune Wheel as royal (the material and the temporal). On the Square of Opposition, the subject on the left and right verticals and upper horizontal of the square are different while the lower horizontal of the square's subject is the 
same. The predicates on all corners of the square are the same. A predicate is a category, and a subject is an entity or identity. The similarity of category and the difference of the subject suggests different identities but one meaning like the Trinity. This is like the approach to the Woman with the Skull from the perspective of the Pope. On the Wheel of Fortune, the divesting of the figure of his crown makes him the same in subject, but different in category (royalty to citizen). This is the perspective of the royalty which is like the art historical perspectives seen in the literature. The dream that the Woman with the Skull is one historical identity putting on many roles has been pursued by endless scholars (to be discussed below), but the idea that she can be many identities as wife, sister, and daughter (and thus, as occupying many spaces on the tree of consanguinity) and many personalities as Constance, Urraca, and Urraca, breaks the cycle of being a stable category to superposition over historical figures.

\section{Original Sin and Language}

If Original Sin is seen as a situation arising from inclusion and exclusion of senses, many biases of scholarship are revealed. F. P. Pickering identifies the word as having priority over the image. ${ }^{43}$ However, this is a bias that presumes that social structuring and construction relies predominantly on language. In the case of the papal reading of the legend in the Pilgrim's Guide, the relationship between the papal as maintaining orthodoxy with language is upheld. Many of the biases of orthodox Christianity depend on this stereotype. Only by diversifying this opinion to include scholarship that looks to the image as also retaining some power in the struggles between word and image can a balance be achieved. While the 'orthodox' view is one that privileges language, there needs to be a mining of the cracks that this topos produces to give the representational a voice. This article maintains that language's superiority over imagery is a matter believed to be controlled by the stereotype of papal control leaving outliers to the verbal who instead, retain heretical impulses, but a potentiallyunmined guide for future interpretations. At the end of Genesis 2, Eve and Adam share the same experiences and Adam is the origin of voice

\footnotetext{
${ }^{43}$ F. P. Pickering, Literature \& Art in the Middle Ages (Coral Gables: University of Miami Press, 1970), esp. 75-91.
} 
as the "two in one flesh." 44 While Eve remains without speech until the serpent's entrance into the scenario; this dichotomy suggests the symbiosis of roles in which Adam hears and speaks and Eve sees. This is similar to Adam and Eve as a Christian construct for the blind but hearing Synagoga and Eve as the deaf but seeing Ecclesia. Together, they act in unison and understand in unison. The serpent calls for the expansion of Eve's roles in the body of the two of one flesh makes the body divide when roles are diversified. While a violation of consanguinity is the assumption of an 'inappropriate' physical role allotted to another physical relative, she takes the physical role of hearing and speech upon herself. This introduces a division of the two of one flesh, the intake and emergence of sound from Eve which has been the identity of Adam. Adam then takes the role of visual imitation upon himself as his new physical role. Edenic paradise may not be paradise after all as it is a demarcation and inflexibility of roles. The idea of Original Sin as necessitating a clothing of nudity is the idea of Adam and Eve seeing and understanding their bodies and selves as not one flesh.

They recognize that when they each participate in language dissemination it is subjective and that they both, being endowed with the power of vision, change the nature of witness. The rules of language and subjective misunderstandings get coloured as shameful. Similarly, at this phase in science understandings, animals like the ram and lion cub have not been proven to have a sign-based language system, but humans do. The idea of 'dressing' a meaning in a word is like clothing nudity. When the dressing of a meaning is close to mutual (as it is in "two of one flesh"), there is a union between the deliverer and the receiver. This sharing, however, is not traditionally easy to establish. The like visuals of the drapery coverage and absence of drapery on diagonals counterpositions the ' $\mathrm{X}$ ' across the body of the Woman with the Skull (like the Wheel of Fortune) as representative of contextually non-human forces covering a language-tainted body (Square of Opposition) subject to Original Sin. Conversely, the Woman with the Lion Cub suggests drapery controlled by humans (balanced on either side) and a body controlled by nature (turning in space, Fig. 9).

44 The Holy Bible (Rockford, IL: Tan Publishers, 1971), 7. 


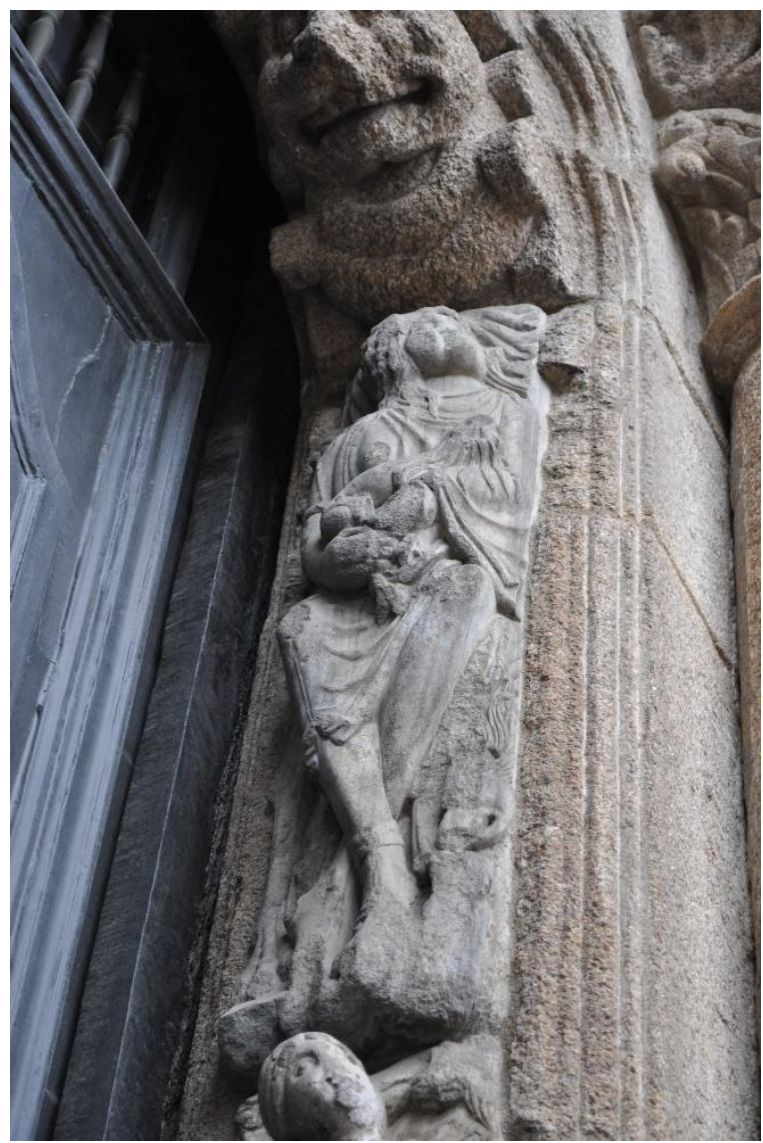

Fig. 9. Woman with the Lion Cub, Right Jamb of Right Doorway, South Portal, Santiago de Compostela (photo: the author)

\section{Contextualizing the Fragment}

The Woman with the Skull as Ostracized and Defined as Fragment

Confined to a cramped corner of the tympanum (Fig. 2), the Woman with the Skull's voluminous head of hair is partially cut away on the proper left and part of the curve of her proper left shoulder is amputated to fit the curvature of the tympanum. She sits upon a sella curulis or faldistorium and embraces in her parenthetical arms a skull 
missing its lower jaw. ${ }^{45}$ The Woman is sitting with her legs somewhat parted to reveal the musculature of her proper left leg while her proper right leg is draped by a cascade of curving parallel folds. Her upper body is an inversion of dress and undress seen in her lower body. The proper right breast is exposed like a captive land according to Moralejo and the proper left is covered with a drape. ${ }^{46}$ The chiastic placement of the dress is the opposite of the up and down trajectory of her body which is unlike another iconographic oddity, the Woman with the Lion Cub. The Woman with the Lion Cub has equal forces on the left and right of her drapery so that they cover her completely, but, unlike the Woman with the Skull, her legs are crossed.

There are many readings of the Woman with the Skull. Azcárate calls her 'Eve as Mother of Death,' Amil-y-Castro considers her Mary Magdalene, Rückert defends her as Bathesheba, Mathews loosely proposes Queen Urraca, and there are other associations of the Woman with blanket sinfulness and monstrosity. ${ }^{47}$ The Romanesque is replete with general monstrosities like hybrid creatures and this study definitely sees how the Woman fits into this category, but the Woman so often falls into the vacuous black hole of either macabre categorization or the finger-pointing related to a specific personage. This study approaches the Woman with the Skull as an imposable template of punishment reliant on infamous Biblical women, but used as a tool applied to at least three historical figures in Alfonso VI's life: namely, Urraca (sister of Alfonso VI, 1033 - 1101), Urraca (daughter of Alfonso VI, likely born late $1080-1126)^{48}$ and Constance of Burgundy (second wife of Alfonso VI, married in 1079). ${ }^{49}$ The superpositioning of the three

45 Sastre Vázquez, “La Portada de las Platerías,” 183.

46 Serafín Moralejo, "Codex Calixtinus as an Art Historical Source," in The Codex Calixtinus and the Shrine of St. James (Tübingen: G. Narr, 1992), 218, ftnt 24.

${ }^{47}$ José Villa-Amil y Castro, La cathedral de Santiago: breve descripción histórica con la planta y un diseño iconográfico (Madrid: Tipografia de la Revista de Archivos, 1909), 32, Karen Rose Mathews, "'They Wished to Destroy the Temple of God,' 204-206, Azcárate, "La portada de las platerías," 1-20, Williams, "La Mujer del cráneo," 13-28. For extensive bibliography on the Woman, see Stones, Krochalis, Gerson, and Shaver-Crandell. Newer studies are also incorporated throughout this essay in addition to the reading of the woman as Bathsheba in Rückert, "A Reconsideration," 129-146.

48 Bernard F. Reilly, The Kingdom of León-Castilla under King Alfonso VI, 1065 - 1109 (Princeton: Princeton University Press, 1988), 192.

49 Though Mathews indirectly proposes Urraca as an interpretation, this essay sees the blurring of Urraca's relational category with her mother, Constance, and her aunt, 
personages into a hybrid symbol carries its own monstrous implications. In this way, the Woman and her story become a means to malign women generally, but also in a stealthy way that makes the figure of the Woman with the Skull general enough for public mass humiliation and specific enough to communicate a papal point of view to the royal family. On one hand, the woman is physically and materially manipulated to occupy the space on the south portal. This state maintains her status as materially-flexible in a royal way. On the other hand, she was prior to this conversion, separated and ostracized from her original position. The idea that the Woman is a whole person made into a fragment by the system is part of how the papal constructs and royal familial constructs debase the mythically 'whole' individual.

As this study relates Alfonso VI's real or legendary treatment of sister, daughter, and wife as physically available in the same ways, consanguinity and incest become inevitable topics. Pope Gregory VII accused Alfonso VI of incest in his letter of 1080, which is meant to discipline the king and warn him of potential downfall. Gregory VII may be alluding to Constance when he refers to a 'perditam feminam' (line 27) and the issue of simony with the monk who he names, Robert of Sahagún, 'pseudomonachum' (line 26). ${ }^{50}$ It has been interpreted that the consanguinity accusation relates to Alfonso VI violating the fourth degree of consanguinity in his marriage to Constance of Burgundy due to his prior marriage to her cousin, Inés of Aquitaine. ${ }^{51}$

The idea that the papacy and royalty follow inverted purposes relates to the long-standing Investiture Struggle. ${ }^{52}$ Bernard of Clairvaux

Urraca, as the core and direct purpose of the Pilgrim's Guide interpretation. Mathews, “'They Wished to Destroy the Temple of God," 204-206. Joseph F. O'Callaghan, "The Integration of Christian Spain into Europe: the Role of Alfonso I of LeónCastile," Santiago, Saint-Denis, and Saint Peter: The Reception of the Roman Liturgy in LeónCastile in 1080, ed. Bernard F. Reilly (New York: Fordham University Press, 1985), 101 120, esp. 107 and 110.

50 Catholic Church, and Erich Ludwig Eduard Caspar. Das Register Gregors VII. Monumenta Germaniae historica. Epistolae selectae. Tomus II, (Berlin: Weidmannsche Buchhandlung, 1920), VIII, 3, pp. 519-520.

51 Reilly, The Kingdom of León-Castilla under King Alfonso VI, 109.

52 One general example of the idea of life and death in investiture by the material sword or the spiritual sword is the nomination of Wazo (d. 1048) by Henry III. Wazo indicates that anointing by a sacerdotal authority far exceeds that of a royal consecration in the same way as life does death. As stated earlier, the idea of life is the conceptual impressing upon the material in a pre-meditated way while the material 
addresses the conflict between the investiture with the material sword and the spiritual sword in rulership of kingdoms and the Church. ${ }^{33} \mathrm{~A}$ spiritual or temporal power is rooted in the conceptual while a material sword is rooted in the bodily. The idea that material power is related to capital punishment seems likely and would seemingly relate to royal power; ${ }^{4}$ however, it may also relate to sexual rules like consanguinity and would become of papal concern.

The comparison of simony and incest creates an inverse parallel of identity conflation. Simony or the selling of church offices acts as the conversion of the priceless and universally spiritual to the finite, particular, and worldly. The idea of consanguinity violations is the consolidation of familial roles into one person. Like the conflation of the spiritual/upper and the worldly/lower, consanguinity that pushes prior consanguineous relatives into the multiple familial occupations marks a merging of those on the left and the right of the two people examined in the arbor consanguinitatis (comparative table of familial relations of two people, Fig. 4). In the letter, the description of the woman decries her perfidy. This infamous description becomes even more expansive in an eleventh-century Arabic story where Alfonso VI is accused of having had incestuous relations with his sister. Notably, Alfonso VI's sister is named Urraca, which is the same name Alfonso VI gives to the daughter he fathers with Constance. The Arabic tale gives voice to comparisons of this group of Spanish royalty to the Egyptian pharaohs, the Persians, and to magicians.

impressing the conceptual relates to death as it is in the artistic production of the portal. The material on the material is an apostatic treatment. For Wazo, see Uta-Renate Blumenthal, The Investiture Controversy: Church and Monarchy from the Ninth to the Twelfth Century, trans. Uta-Renate Blumenthal (Philadelphia: University of Pennsylvania Press, 1988), 87.

53 Gerhard Ladner, "The Concepts of "Ecclesia" and "Christianitas", 58

${ }^{54}$ Ladner, ibid. 


\section{The Virgin Mary as 'Whole' Fragmented by Context}

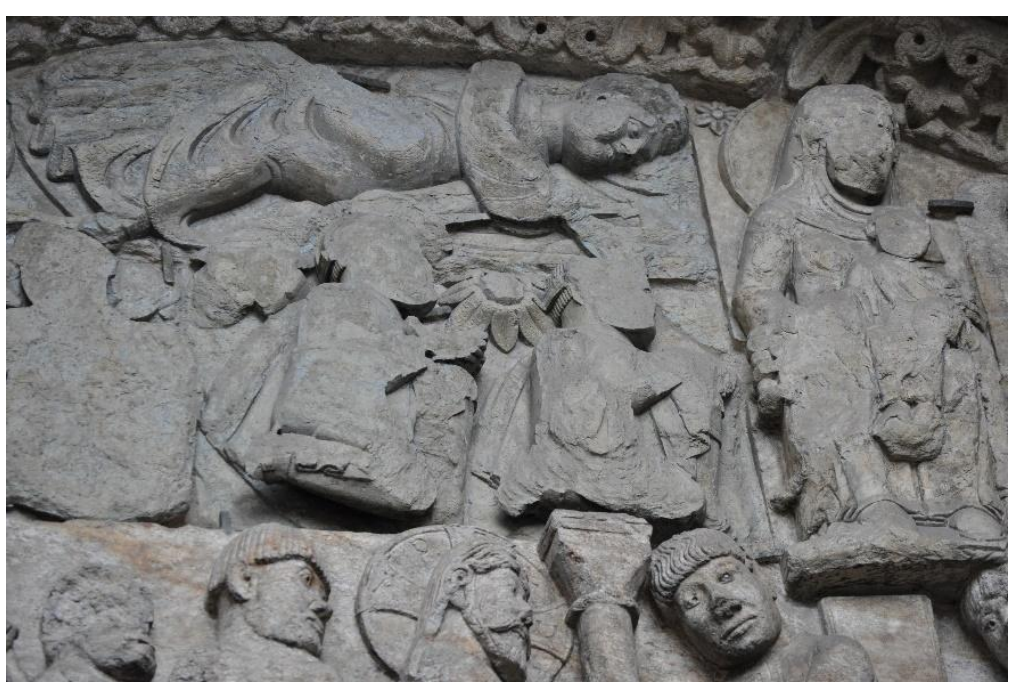

Fig. 10. Adoration of the Magi with frontal Virgin, Right Tympanum, South Portal, Santiago de Compostela (photo: the author)

Importantly, the coupling of the Woman with the Skull in the periphery of the left tympanum with the Virgin Mary (Fig. 10) in the centralized scene of the Adoration of the Magi in the right tympanum, sets up a dichotomy that cannot be ignored. Through the words of the Pilgrim's Guide, the idea that iconography as language imposes restrictions on the Woman counterbalances the material state of the Woman as fitting a new material or familial role. The words that establish the Woman's iconography make her a papal statement while the material situation makes her a royal statement. Similarly, the royal relationship of the iconography of the Adoration of the Magi on the right tympanum relate to the written as, in this case, royal, and the material in white marble as ,pure' and papal. ${ }^{55}$ Significantly, if the Woman with the Skull is conceptually bound in marriage like the legend of the Pilgrim's Guide maintains (making her adulterous in her affair), her material/sexual

55 Significantly, the Woman with the Skull is made of gray pegmatite and the Virgin Mary is made of white marble with associations of purity. J. M. Cabrera, I. Seara, and J. de Miguel, "Portada de las Platerías," 34. 
transgression results in conceptual and material punishments of perpetual representation of her sin and the physical punishment of having to kiss the decapitated head. Thus, the left tympanum may suggest the material and spiritual sovereignty in dispute between royal figures and papal figures.

The Pilgrim's Guide presents a concept through the Woman that dictates the conceptual judgment of material individuals' physical bodies. For example, in the 1117 riots at Santiago that resulted in the burning of the transept, the rioting crowd divested Urraca (the daughter of Alfonso VI) of her bodily dress which was pushed up around her head resulting in her humiliation. ${ }^{56}$ This event may be based upon the dress of the Woman with the Skull, which exposes her right breast. Additionally, this use of a concept and its imposition on the material relates to larger uses of categories in language and in linguistic diagrams like the Aristotelian Square of Opposition and royal diagrams like the Wheel of Fortune.

While Lyman suggests a Romanesque penchant for teaching through the profane, ${ }^{57}$ Jaeger discusses the idea of imitation and disputation in the cathedral schools. ${ }^{58}$ This is not necessarily a completion of a typology as it is typically defined as positive and negative (i.e. imitate the sacred and dispute the profane), it is more specifically a type and its opposition through the turning inside-out of the first; it is an inversion. Sastre's allusion to the Hortus Deliciarium and the Woman with the Lion Cub is important to acknowledge this treatise and its relationship to the Trivium (language) and the Quadrivium (science). ${ }^{59}$ The Square of Opposition (though its name suggests

56 Emma Falque Rey, ed. Historia Compostellana (Turnholt: Brepols, 1988), Book I, Chapter 114, Part 3, lines 119-130. For translation, see Thérèse Martin, Queen as King: Politics and Architectural Propaganda in Twelfth-Century Spain (Leiden: Brill, 2006), 192.

${ }^{57}$ Lyman, "Motif et narratif," 63.

58 In Jaegar's The Envy of Angels, the entire study examines the school of manners (charismatic culture), which is considered old learning and which is supplanted by disputational learning.

59 Sastre Vázquez, "La Portada de las Platerías," 186; for early thoughts on the relationship of marriage and the liberal arts in Latin allegories like De nuptiis Philologiae et Mercurii, see commentary and Capella's text in William Harris Stahl, Richard Johnson, and E. L. Burge, Martianus Capella and the Seven Liberal Arts. Vol. I: The Quadrivium of Martianus Capella: Latin Traditions in the Mathematical Sciences 50 B.C. - AD 1250 with a Study of the Allegory and the Verbal Disciplines (New York, Columbia University Press, 1971), Vol II. The Marriage of Philology and Mercury, Trans. William 
otherwise) relates to imitation through application of a grammatical or rule-based system on an individual (i.e., Trivium) and the Wheel of Fortune relates to disputation as friction and gravity (a subconscious nod to natural laws, i.e. Quadrivium).

The idea that the Pope would involve himself in issues of procreation and sexual conduct is furthered when considering the differences between the perceived rights of God and the perceived rights of humans. Mary, who is Immaculately Conceived, redeems Eve's Original Sin in an equally ambiguous way; however, while Eve is actively ambiguous (actions of taking the fruit result from ambiguous inclinations), Mary is passively ambiguous (body is ambiguous). ${ }^{60}$ There is ambiguity in God's act of impregnating a human in the Christian perception of the events that took place in Mary's life. The deified as having the right to cross the boundaries of category to impregnate the human is seen as permissible by a Christian god, but not by a Jewish one. Conversely, in Christian perspectives, humans are typically not allowed, for example, to move across boundaries of species in their sexual mores. The seemingly prevalent idea could be assumed that Mary is a virginal body selected for material evolution. As a virgin, she is conceptually female, but male as virgin in physical body, making her an example in subject as a sword that is material and temporal/conceptual. The south portal's use of a scene of the Adoration of the Magi suggests the emphasis on the royal side of Jesus' designation. Mary is an example of the evolution of a masculine body given female powers of procreation. The masculine body that can procreate is essentially an evolutionary body.

\section{Adam and Eve as the Conjoined Whole}

On the other hand, in her actions in the Garden of Eden, Eve is also proactively evolutionary, although conceptually instead of bodily. The idea that the Garden of Eden was a forum in which Adam and Eve exercised free will towards a Fall stemming from the act of imitation

Harris Stahl, Richard Johnson, and E. L. Burge (New York : Columbia University Press, 1977).

${ }^{60}$ Questions about Mary's body were still being debated in the nineteenth century when the Immaculate Conception was established as a doctrine. For specific ideas in Hispanic poetry in the late Middle Ages, see Lesley K. Twomey, The Serpent and the Rose: The Immaculate Conception and Hispanic Poetry in the Late Medieval Period (Leiden: Brill, 2008). 
was introduced by the heretic, Pelagius. ${ }^{61}$ The distance between Augustine's pre-Pelagius definition of originale peccatum which occurs in Augustine's treatise, To Simplicianus versus his later life redefinition in light of Pelagius, suggests that the first treatise promotes an individual kind of sin based on one's own actions instead of a universal one. ${ }^{62} \mathrm{In}$ the context of subject-object perception, the relationship of the name Simplicianus to Simplicius is tantalizing. The subject of Original Sin is commonly used by scholarly arguments concerning the south portal due to the many scenes of Adam and Eve that were moved to the south from the north portal. ${ }^{63}$ Azcarate even considers the Woman with the Skull's identity to be Eve as Mother of Death. ${ }^{64}$ This idea is important, but also important for its establishment of a dichotomy between Mary as a static body appropriated for conceptual change and Eve's conceptual action as resulting in bodily change. 65 The notion of evolutionary conceptual manipulation in Genesis' second creation story and bodily manipulation in the story of Jesus' birth suggest the law of 'nature' or 'God' as encouraging evolution. On the other hand, canon law suggests that the idea that the Pope regulates or even prohibits evolution of concept based on Papal attempts to control information

${ }^{61}$ Augustine of Hippo (Augustinus Hipponensis), De peccatorum meritis et remissione et de baptism paruulorum (Turnholt: Brepols, 2010),

www.clt.brepolis.net/llta/pages/Toc.aspx?ctz-722774 (accessed 22.10.2017), Book 1, Chapter 9. John Ferguson, Pelagius: A Historical and Theological Study. Cambridge: W. Heffer \& Sons, Ltd., 1956, 54.

62 Sage explains that there is a difference between peche d'origine and peche originel. The former is an accusation of hereditary guilt when enacted through one's behaviour. The latter is considered sinful in inheritance from Adam that is based on inherent nature. Also, there are three stages to Augustine's definition of sin. The first stage is based on one's own actions, the second stage is hereditary from Adam through imitation, and the third is inherent to all humanity in spite of actions. Augustin Sage, "Péché original. Naissance d'un dogme," in Studies in Early Christianity: A Collection of Scholarly Essays (New York: Garland Publishing, 1993), 131-168, 211-248, esp. pp. 212, 132. B. R. Rees, Pelagius: Life and Letters. Woodbridge: Boydell Press, 1998, 65.

63 According to the Pilgrim's Guide and its description of the north portal, the physical presence of the Expulsion image on a capital currently on the southern portal was likely on the north. Gerson, Shaver-Crandell, Stones, and Krochalis, ed. and trans. The Pilgrim's Guide: A Critical Edition. Vol. II, 72, 73.

64 Azcárate, "La portada de las platerías," 11

${ }^{65}$ In the ceiling paintings of St. Savin-sur-Gartempe, the figures of Adam and Eve appear as both having beards on their faces and no externally visible genitalia. When Eve is tempted by the serpent, she loses her beard, gains breasts and long blond hair. 
while the royal prevents material evolution by not mixing with the populace.

The right tympanum's image of the Virgin Mary comes with this representation as the concept originating from material royal purity due to Mary's relationship to the lineage of David, but conceptual evolution in cross 'species' procreation for the purposes of the production of Jesus in her womb. There are suggestions that an intact female virgin was considered male who was invested with the material and spiritual seed of God. Isidore's Etymologies indicate that a virago is a 'heroic maiden' who 'acts like a man' while the word virgo is related to a physical descriptor of virga or a young shoot of foliage. ${ }^{66}$ The seeming distinction between a movement that is physically upward and a movement that is an upward in achievement, or in the case of Eve, downward, is here significant. ${ }^{67}$ This makes the physical generation of the son of Mary as the Christian son of God as a bridging of categories similar to crossing species like that of the otherworldly - God, and the human, Mary, or Jesus as son, and Mary as spiritual spouse. Thus, this tympanum suggests the royal evolution of the material into the papal conceptual as equally important: the material that precedes the concept - the Woman's state before being put in the tympanum and the conceptual reintegration (resulting in a ragged cutting and visceral sentence of perpetual representation) as investment in the punishment of the Woman with the Skull.

Material and conceptual concerns also interject themselves into the historical and symbolic realms. The definitions of history and symbolism have changed over time, but they also change based on the discipline. In a scientific perspective, history is factual while in the realm of language, history is subjective. Meanwhile, in a scientific optic, symbolism is subjective while in language, symbolism/semiotics is the organizing principle and in a way, as a system within and as a construct, is factual. Similarly, in the medieval mindset, there could have been two different approaches to history and symbolism that is highlighted in particular by the royal and the papal. In the case of the royal Virgin Mary who can be compared to the Wheel of Fortune and science,

\footnotetext{
${ }^{66}$ Isidore of Seville (Isidorus Hispalensis), Etymologiae, PL, 82, 417D; Etymologies of Isidore of Seville, Book XI, ii, 21 and 22, p. 242.

${ }^{67}$ Martin compares Queen Urraca through her own authority and action as 'Queen as King' in Queen as King, esp. chapter 7, 177-207.
} 
history is imposed over symbolism. The factual, scientific material is imposed over the subjective categories. This means that the ambiguity of the categories of morality imposed by the church are subjective and consanguinity limitations are overturned for scientific realities. Thus, while Mary's virgin birth is canonical, the origin of Mary is precisely royal in its preservation of material bloodline, but the crossing of boundaries of reproductive capabilities violates so-called concept of species (God and human) for making the papal construct conceptually realizable.

\section{The Application of the Inverted Papal Linguistic 'Whole' versus the Royal Scientific 'Whole'}

Likewise, the Woman with the Skull represents the linguistic optic used as the papal punishments for violations of sexual taboos between humans. The Adulterous Woman is an example of a woman who is born into a pre-established context and already existent standard of social rules that dictate material behaviour while Mary as material precedes her conceptual circumstances and adapts to them. De Avibus, which is the book where the Wheels of True and False Religion are found, supports transitions between secular context and monastic context. ${ }^{68}$ Like the investiture controversy, the idea that the contextual is in the realm of law and the internal is in the realm of religion is the main idea in the Wheels in De Avibus.

The initial production of the Woman with the Skull may have been to vilify the sister of Alfonso VI, Urraca, who does not marry, but materially would be punished for her incestuous relationship. The Woman with the Skull, like in the instance of Constance, separates the contextual and material transgression of the degrees of consanguinity, but acts in a different and internal moral violation of the religious by supporting the monk, Robert. This separation may be marked by the disconnection of the Woman with the Skull from her believed position on the north portal. Like the Signs Relief which was cut, but never known to have been placed, the separation of the plaque like the

\footnotetext{
68 This is because the text is directed at conversi or lay brothers who converted to a monastic lifestyle from a secular lifestyle. This hybridity, displacement, and integration has pertinence to the south portal at Santiago. The Medieval Book of Birds Hugh of Fouilloy's Aviarium, 2, $116-117$.
} 
Woman may have marked some significant occurrence. ${ }^{69}$ Urraca (the daughter of Alfonso) in having her father as her consanguineous lover, she simultaneously breaks both her internal, religious, conceptuallyderived marriage vow to Raymond of Burgundy and violates the bloodline laws that are contextually pre-determined to material/genetic circumstances. By violating these rules, she is both materially and conceptually punished by the insertion of the Woman with the Skull on the south portal. In this case, the imposition of symbolism over history suggests that the organizing principle of language dictates the subjective history of the person. The inflexibility of grammar is an apt comparison for the punishment that superpositions regulations over subjective experience. ${ }^{70}$

While this study is less concerned with a pre-riot message, Castiñeiras implies that narration is the key to understanding the original message of the tympana prior to the 1117 . While Castiñeiras also relates the program to reform, he uses the date of the Capilla del Salvator in the ambulatory, the date on the south portal, and the date of the coronation of Alfonso VII (discussed by John Williams) as a way of marking priority of the building shifting from the chapels to the facades. Castiñeiras believes the façades correspond to texts like the Polycarpus that stress narration/history as the venerated thing in art. By taking the narrative of the Temptation of Christ on the left portal as the original subject of the tympanum prior to riots, Castiñeiras asserts that the Italian reform is responsible for the message and the urgency of relaying it in the portals. ${ }^{71}$ While Castiñeiras sees narrative as a preconceived arrangement prior to the riots in the form of a narrower tympanum with only the temptations narrative, interestingly, this narrative is stylistically homogenous and materially homogenous. This narrative is compromised with the riots. Also, in life, when narrative is arrested, material engulfs the conceptual to its completion in death. A

\footnotetext{
${ }^{69}$ Durliat, La sculpture romane, 412.

70 According to John of Salisbury, Bernard of Chartres punished his students when they used grammatically incorrect language with floggings. Joannes Saresberiensis, Metalogicon, PL, 199, 854A; John of Salisbury, Metalogicon: a twelfth-century defense of the verbal and logical arts of the Trivium, trans. Daniel D. McGarry, (Berkeley: University of California Press, 1955), Book I, Chapter 24, p. 68.

71 Manuel Antonio Castiñeiras González, "La catedral románica: tipología arquitectónica y narracion visual," in Santiago, la Catedral y la memoria del arte (Santiago de Compostela: Consorcio de Santiago, 2000), 39-96, esp. 61-62.
} 
history of a person from birth to death begins with the material and its accumulation of the conceptual while the end of life is the conceptual narrative accumulating physically-distorting changes. Unformed material acquires conceptual direction in art and usually, it is premeditated. When conceptually-directed material is materially acculturated to be unrecognizable, it is related to death. If the conceptual material is conceptually and materially reused, it relates to resurrection. The persistence of the Temptation narrative in interpretation of the tympanum suggests that this last option is the end result of the portal in that the conceptual organization and material accumulation persist alongside one another.

In language, category acts as the clothing of meaning as symbolism in which a linguistic sign encloses its meaning. This relationship is seen in the Woman with the Skull who is categorically isolated while the Virgin in the adjacent right tympanum is positioned in the Adoration of the Magi narrative. The juxtaposition of these two examples also appears in Spain in the Sarcophagus in Roda de Isàbena of and also in Roda de Isàbena in the faldistorium of Ramón I. The Woman with the Skull appears seated on a faldstool or scissor-legged chair with lions heads at the top and animal feet at the bottom. Very similar in sculpting is this stone representation and the wooden faldstool that Ramón I sat upon (Fig. 10). Ramón was originally an Augustinian monk at St. Sernin in Toulouse where the Signs Relief is located further connecting the Woman with the Skull's seat and the sign of the ram with the decapitated skull. Ramón was originally assigned to be the archbishop of Barbastro and then, due to discord in the kingdom of Aragon, he was displaced to Roda. ${ }^{72}$ This was happening during the tumultuous marriage of the daughter of Alfonso VI, Urraca, to Aragon's leader, Alfonso le Batallador. ${ }^{73}$ The potential etymological root of Barbastro with the later term from the Spanish, bastardo, holds further relations to the seat of the Woman with the Skull and Urraca's birth of a son that

\footnotetext{
${ }^{72}$ Manuel Iglesias Costa, Roda de Isabena, Jaca: Monografias del Instituto de Estudios Pirenaicos, 1980, 117, 130.

${ }^{73}$ Urraca was consanguineously related to Alfonso le Batallador. They shared the same great-grandfather in Sancho the Great of Navarre. Urraca's original husband who is considered the father of Alfonso Raimúndez also shared a great-grandfather with Urraca in Robert the Pious. Reilly, The Kingdom of León-Castilla under Queen Urraca: 1109 1126,58 .
} 
may have been fathered by a man not her husband and possibly her own father. The relation of the word, bastard, with 'saddle bags' has an ironic relationship to the Adoration of the Magi and the traveling parents of Jesus. Ramón was also buried in a sarcophagus with the Adoration of the Magi carved on its side (Fig. 11). ${ }^{74}$ The idea that the historical narrative of Adoration dresses the symbolic disappearance of the body can even be related to Jesus' Ascension while the symbolic tool houses the historical figure in the space for sitting on the faldstool. Similarly, the body of the Virgin Mary is historical narrative, dressing the symbol and the indictment of the Woman with the Skull is symbolism dressing history. Even Willibald Säuerlander remarks on the transformation of symbol to narrative in French Romanesque art when in context. ${ }^{75}$ The idea that Santiago is out of context makes the narrative transform into symbol.

According to the histories of the Spanish royal family (whether accurate or not), Alfonso VI's daughter, Urraca, is said to have never had a successful love life and was often stereotyped as lascivious, sexually unfaithful, and user of her sexuality as a weapon. ${ }^{76} \mathrm{Her}$ marriage to Alfonso le Batallador resulted in much strife and disturbance in Spain. ${ }^{77}$ While the shadowy history of Urraca's sexuality persists in rumours, murky allusions are made to consanguineous impropriety including the marriage of Urraca at the age of eight to Raymond of Burgundy (instead of canon law's stipulation of the age of twelve), while a letter of unverifiable date adds to the conflatable histories of Alfonso VI's female relatives. ${ }^{78}$

\footnotetext{
74 "Bastard," Oxford English Dictionary (Oxford: Oxford University Press, 2013), accessed 22.10.2017 (www.oed.com).

75 Willibald Sauerländer, "Romanesque Sculpture in its Architectural Context," in The Romanesque Frieze and its Spectator: The Lincoln Symposium Papers, (London: Harvey Miller Publishers, 1992), 17-44. Republished in Romanesque Art: Problems and Monuments (Volume 1) (London: Pindar Press, 2004), 1-35.

76 Reilly, The Kingdom of León-Castilla under Queen Urraca: 1109 - 1126, 13, 46-48, 60.

77 Reilly, The Kingdom of León-Castilla under Queen Urraca: 1109 - 1126, 47-48.

78 Although the letter is too early to relate to Alfonso's daughter. Reilly, The Kingdom of León-Castilla under King Alfonso VI, 108.
} 


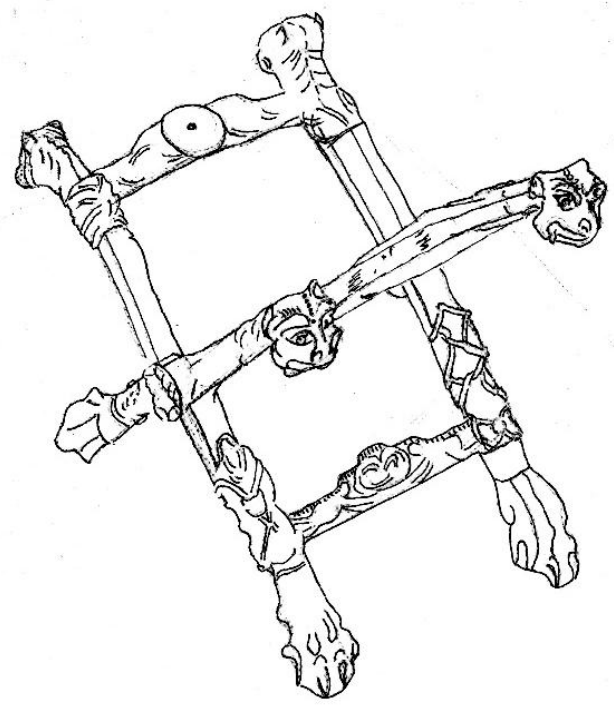

Fig. 11. Faldistorium of San Ramón

(for original, see Manuel Iglesias Costa, Roda de Isabena, Fig. 62)

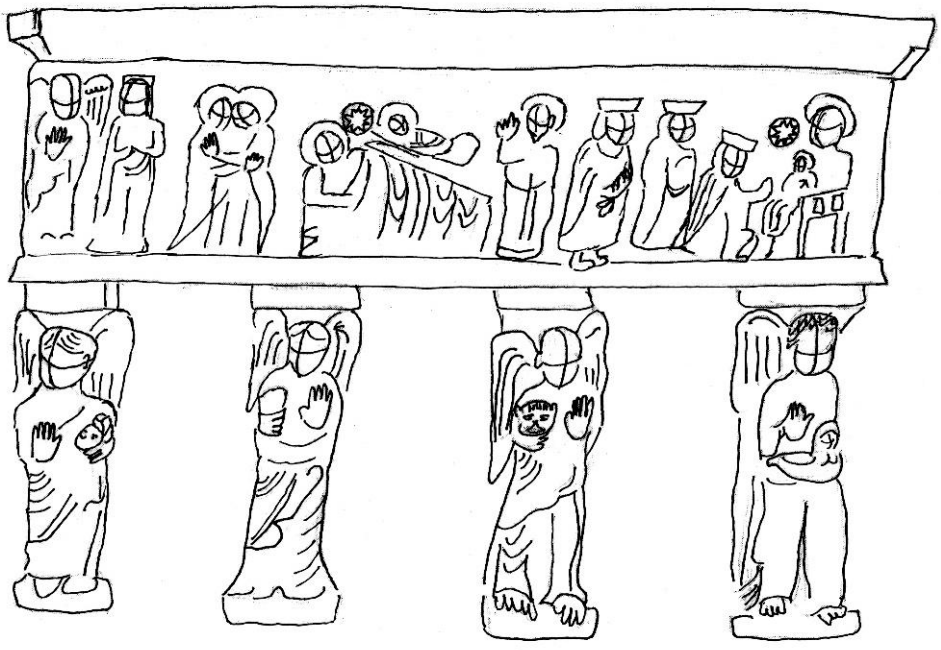

Fig. 12. Sarcophagus of San Ramón

(For original, see Manuel Iglesias Costa, Roda de Isabena, Fig. 41) 
While the status of the Woman with the Skull retains wretched punishments in the Pilgrim's Guide, Walter Cahn maintains that a specific verification of the Woman with the Skull according to the Guide is unlikely. ${ }^{79}$ While I perceive that the importance of the Woman with the Skull rests in her usage as a tool of persecution, perhaps Cahn's observation can still be questioned based on a written precedent other than the Pilgrim's Guide. Royal intrigue in Lombardy in the year 567 insinuates itself into the conversation based on the history of Albion and his father-in-law's skull in Paul the Deacon's Historia Langobardorum. 80 When the barbarian, Alboin, ascends to the throne of Lombardy, he demands that the father of Rosamund, Cunimund, give this same daughter to him in marriage. In spite of refusals, Alboin kills Cunimund and takes Rosamund as wife while serving her wine from her father's skull. In turn, she kills Alboin. Albion is then buried "sub cuiusdam scalae ascensu." 81 Earlier in the narrative, scala is defined as a 'skull cup.' It can also be defined like a staircase. In Fig. 4 of the consangunity tree, the head is combined with the staircase. The shape of a staircase takes on the shape of consanguinity trees and marks the diagonal position of a father to a person on prototypes of these trees.

The story told by the Pilgrim's Guide is that the Woman with the Skull has a lover who is killed by her rightful husband and that it is her lover's head that she must kiss. ${ }^{82}$ By not comparing these stories, but by superpositioning them, the pairing of the lover with the father suggests

\footnotetext{
79 Cahn, "Romanesque Sculpture and the Spectator," 59-60.

80 Paul the Deacon (Paulus Diaconus), Pauli Historia Langobardorum. Monumenta Germaniae Historica, 48. (Hannover: Hahnsche Buchhandlung, 2005), I. 27 [In eo proelio Alboin Cunimundum occidit, caputque illius sublatum, ad bibendum ex eo poculum fecit.], 80 and 2.28 [...cum poculo quod de capite Cunimundi regis sui soceris fecerat reginae ad bibendum vinum dari praecepit atque eam ut cum patre suo laetanter biberet invitavit.], 104.

81 Pauli Historia Langobardorum, Book 1, 27, "Quod genus poculi apud eos 'scala' dicitur, lingua vero Latina patera vocitatur." [This kind of cup is called a 'scala,' but in the Latin tongue is called the bowl.], 80. Book II, Chapter 28, p. 106. The later reference to "Giselpert" in the Historia may be a clue to the importance of this story to Romanesque art and the Gislebertus mentioned in the inscription at Autun whom records maintain could have been the Gislebertus employed as buticularius or 'cup-bearer.' See Linda Seidel, Legends in Limestone: Lazarus, Gislebertus, and the Cathedral of Autun, (Chicago: The University of Chicago Press, 1999), 15, 59, 70.

82 See footnote 13 above for Pilgrim's Guide excerpt about the Woman with the Skull's verbal narrative.
} 
categorical consanguinity violations. Further, by superpositioning the historical upon these stories, consanguinity violations might point to Alfonso VI as the father and lover. While this may be insinuated, the identity of Cunimund with defeat would definitely be disputed by the Spanish royals. The identification of the rightful husband with the conquering party, here, the regional category of Italy, suggests papal identity and approval, but the subject of a barbarian would not be considered acceptable.

If this story was a prototype, it has been tailored to make Italy legitimate in offensive category (Italian regional category) but not in defensive subject (a barbarian identity). The original father is illegitimate and immoral in defensive category (like the incestuous coupling of Urraca and Alfonso VI), but unacceptable as the defeated party. If the father, here, lover, is interpreted as masking Alfonso VI, this reading would make itself appropriate to a mythology begun by Gelmírez (ca. 1069 - 1140) who over-projects his importance in the manner of a pope or an apostle as expressed in the Historia Compostellana. ${ }^{83}$ By expanding Gelmírez's description to the direction of the papal, he can stand in for Gregory VII in the framing of Urraca as the Woman with the Skull. His tumultuous relationship with Urraca who is disrobed (similarly to the Woman with the Skull) in the 1117 riots, would be furthered through this attribution. But the flexibility of the reading allows Pope Gregory VII to apply the reading to the mother of Urraca, Constance of Burgundy, whose marriage to Alfonso VI was considered a violation of consanguinity too by the Pope in the ambiguously dated letter of 1080. As stated previously, in the eleventh century stories of an Arabic author, Ibn-I $\underline{\text { àr }} \overline{1}$, Alfonso VI is specifically identified as violating consanguinity by having an incestuous relationship with his sister, Urraca. But what other than the imposition of Albion's story over the Pilgrim's Guide account of the woman suggests paternal incest with his daughter by the same name?

Manuel Castiñeiras relates the story of the Woman with the Skull to the story relayed in a harp song of Guerin in Gottfried von

${ }^{83}$ Historia Compostellana, Book I, Chapter 16, Parts 1-3, pp. 38-40; Book II, Chapter 3, Part 1, pp. 222-223; especially Book III, Chapter 10, Part 10, in particular, lines 4-8, p. 434. 
Strassbourg's Tristan und Iseult. ${ }^{84}$ The importance of oral tradition is significant due to the time frame of the Woman with the Skull which evidence in the Pilgrim's Guide places the sculpture no later than 1140.85 Thomas the Britain wrote an Old French version of the Tristan story whose manuscript is estimated to have been in circulation in the 1150s. In fact, the story is believed to have been dedicated to Eleanor of Aquitaine who divorced Louis VII in 1152 due to consanguinity violations. ${ }^{86}$ In this version of the story, Tristan sings the tragedy of Guerin in chapter xxii, but later in the story in chapter lxx, the lay is sung by Ysolt in her chamber when she learns that Tristan has already married a different woman with her name, Ysolt of the White Hands. In the lay known as that of Guerin, a woman is forced to eat the heart of her lover killed by her husband. ${ }^{87}$ This story is particularly relevant to Santiago due to the interpretation of the twisted marble column fragments from the north portal and now in the Cathedral Museum as relating to the Arthurian tale of Tristan and Ysolt. ${ }^{88}$ In Thomas of Britain's version, the second appearance of the song is in the moment of the story when Tristan marries another woman with the name Ysolt, suggesting ideas of more than one person acting in the same role. The idea of two women with the same name being superpositioned one

84 Manuel Antonio Castiñeiras González, "Didacus Gelmirius, Patron of the Arts. Compostela's Long Journey: from the Periphery to the Center of Romanesque Art," in Compostella and Europe: The Story of Diego Gelmirez (Milano: Skira, 2010), 16-97, esp. 77

85 Alison Stones, Jeanne Krochalis, Paula Gerson, and Annie Shaver-Crandell, The Pilgrim's Guide: A Critical Edition. Vol. I, The Manuscripts: Their Creation, Production and Reception. London: Harvey Miller Publishers, 1998, 14-15.

86 Though 1152 postdates the evidence of the sculpture, it attests to a pattern related to consanguinity metaphors. For dedication, Roger Sherman Loomis, "Introduction," The Romance of Tristam and Ysolt (New York: E. P. Dutton and Co., 1923), xi, https:/ / babel.hathitrust.org/cgi/pt?id=mdp.39015009017115; view=1up;seq=58

(accessed 03.19.2017). For consanguinity, see Constance Brittain Bouchard, "Eleanor's Divorce from Louis VII: The Uses of Consanguinity," in Eleanor of Aquitaine: lord and lady, ed. Bonnie Wheeler and John Carmi Parsons. (New York: Palgrave Macmillan, 2003), 223-235, 223. Louis VII was related to Eleanor by four degrees on his side and Eleanor was related by five degrees on her side.

87 Thomas of Britain, The Romance of Tristam and Ysolt, Chapter lxx, 195 (marries Ysolt as Blanches Mains) and Chapter lxxii, p. 205 (original Isolde in her chamber laments this marriage). Tristan sings the song in Chapter xxii, p. 35.

88 Serafín Moralejo, 'Cat. 92: Column Shaft decorated with Putti Gathering Grapes,' in The Art of Medieval Spain: AD 500 - 1200 (New York: The Metropolitan Museum of Art, 1993), 212-214. 
over the other is particularly apt in the argument of this essay. Also, the idea that two physically-different women would be used towards the same end, perhaps in Tristan's case the purpose of alleviating loneliness, relates to consanguinity violations that overlap physical relationships. The Muslim tradition maintained that Alfonso VI had an incestuous relationship with his sister, who like in the comparison to Ysolt, bears the name of his sister as another Urraca. Ysolt and Ysolt of the White Hands are two lovers; Urraca and Urraca are Alfonso's sister and daughter. ${ }^{89}$

The ambiguity between consuming a heart and kissing a skull circles back to the idea of Original Sin. While Eve ingested the fruit, there are some legends that attest to the physical body of the fruit from the Tree of Knowledge lodging itself in Adam's throat so that he does not integrate the flesh of the fruit into his being. ${ }^{90}$ If the Woman is someone who ingests, she is related to Eve. If she is someone who carries a material relic constantly with her like physiognomic accretion

89 Though somewhat lofty in assumption, reasonably, the myths of twin worship in the Dioscurides at Santiago can be loosely substantiated with this doubling. It also opens an earlier date potential for the reading of ANF REX on the south portal to refer to both Alfonso VI and Alfonso VII like the doubling of Urraca or Ysolt. Américo Castro, España en su historia: cristianos, moros y judios (Buenos Aires: Losada, 1948). Though Castro's hypothesis about the Cathedral of Santiago's as a Temple of Castor and Pollux seems highly unlikely, there is a theme of doubling in the history. The temple dispute is supported and contested by studies listed in Maryjane Dunn and Linda Kay Davidson, The Pilgrimage to Santiago de Compostela: A Comprehensive, Annotated Bibliography (New York: Garland Publishing, 1994): see the numbered entries of support in Guillermo Arraya (91), and Alexander Haggerty Krappe (1565), and numbered entries in opposition in Jerome O’Malley (2093), Justo Perez de Urbel (2212), Claudio Sanchez-Albornoz (2496, 2498), and Casimiro Torres Rodríguez (2691). More discussions by Castro are found in bibliography entries numbered 480, 481, and 483.

90 The tradition of the origin of the Adam's apple is visually shown with Adam grabbing his throat in Spanish Romanesque art. Examples are the Capilla de la Vera Cruz de Maderuelo (province of Segovia), $3^{\text {rd }}$ quarter of the $12^{\text {th }}$ c. in the Prado Museum (see Pedro de Palol and M. Hirmer, Early Medieval Art in Spain. (London: Thames and Hudson, 1967), Plate XLI (p 153), text on p. 180); J. Gudiol, Die Kunst kataloniens, (Vienna, 1937), pi. xxIII, fig. 39; Burgos Bible folio 12v (Art of Medieval Spain, A.D. 500 - 1200, Cat. 152, p. 299); and Juan Ainaud, Romanesque Painting, New York, 1963, figs. 115, 130. For later traditions and etymology of the anatomical throat cartilage, see James Snyder, "Jan van Eyck and Adam's Apple," Art Bulletin, 58/4 (1976): 511-515, see 513-515. 
in the Adam's Apple fable or a skull like the Woman with the Skull, she is like Adam.

\section{Spatial vs. Material Roles and Spatial vs. Material Identities}

The common theme of the same body which can be made to act in different roles is ingrained in the very nature of the south portal. In 1942, Meyer Schapiro identified the inscription on the south portal as having an indeterminate date that can be read as the traditional Roman Numeral 'V' (ICXVI) or as a Visigothic Script Numeral that actually denoted ' $\mathrm{L}$ ' or (ICXLI). ${ }^{91}$ The relevance of this point is not related to the numerical meaning of the date, but to show how the Roman numeral is one body with many meanings like the woman who acts physically as sister, daughter, and wife.

The nature of the date on the south portal of Santiago (Fig. 13) is a blatant display of this Original Sin. The single body that can be interpreted more than one way is the ambiguity of perception of either the Roman Numeral as an 'L' or a 'V.'92 In fact, in relation to degrees of consanguinity and their position on the trees from the Middle Ages to today, when plotting the position of father, brother, and person on an arbor consanguinitatis, a righted 'L'-shape like the Roman numeral results, but with a change of chronology, brother, person, father creates an inverted 'V'-shape (Fig. 14). Only in current consanguinity tables does the plotting of Daughter, Sister, and Person relate to the upright 'V'shape as well as an overturned ' $L$ '-shape. The ambiguity of the reading relates to the ambiguity in the physical relations of Alfonso VI and his family members. The Historia Langobardorum that may help to form the symbolic exemplum of the Woman with the Skull in the Pilgrim's Guide and the 'history' specifically identifying Alfonso VI by Ibn-I dāài has correlations to history being formative of symbolism. The symbolism of the 'history' specifically identifying Alfonso VI by Ibn-I dāāī .

The Woman with the Skull and the south portal of Santiago become a material fulfilment of physical roles of stylistic variation, material variation, and reuse as variation that cooperate in one space. This is like

\footnotetext{
91 Meyer Schapiro, "A Note on the Inscription of the Cathedral of Santiago de Compostela," Speculum 17:2 (April 1942), 261-262.

92 The potential of reading scripts of the same carved numeral differently is a tangible example of 'two in one flesh.'
} 
Spain's convivencia of the religious diversity of Jewish, Christian, and Muslim populations. ${ }^{93}$ As this essay opened its conversation with ostracism as the separation of physical objects from the conceptual majority and conversion is the object being consumed by a construct, the Woman with the Skull as a singled-out identity represents this process. The physical accumulation or subtraction from the portal adheres to the idea of a community with different physical roles.

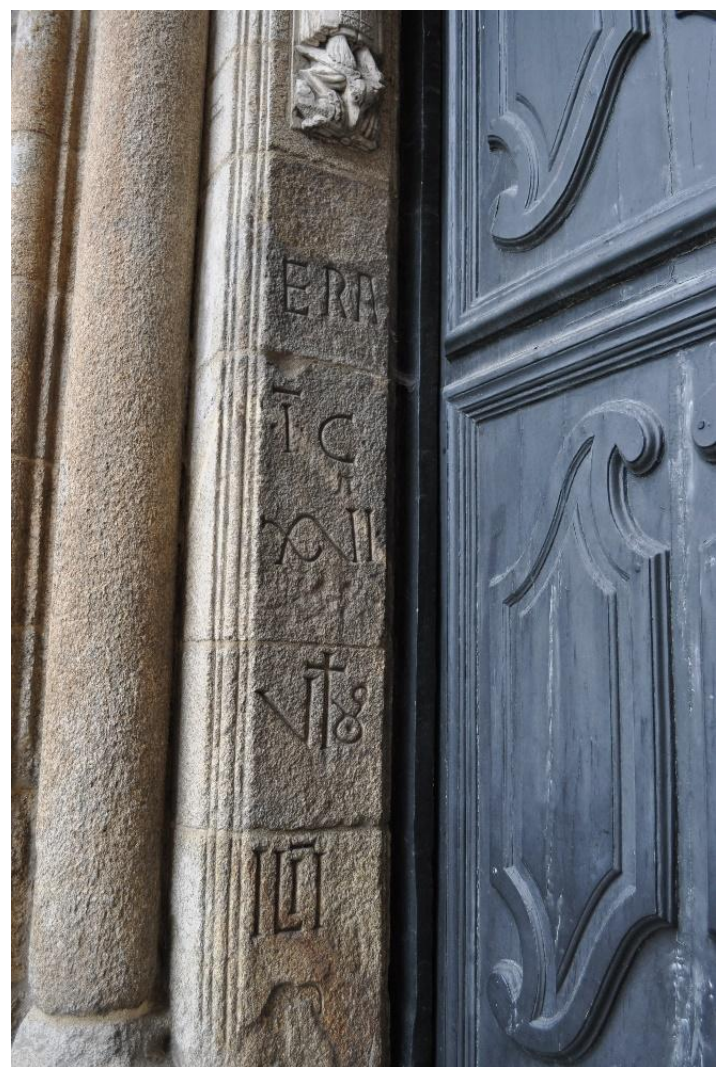

Fig. 13. Inscription on the South Portal of Santiago (photo: the author)

${ }^{93}$ For more on convivencia, see Thomas F. Glick, "Convivencia: An Introductory Note," in Convivencia: Jews, Muslims, and Christians in Medieval Spain, ed. Vivian B. Mann, Thomas F. Glick, Jerrilynn D. Dodds. (New York: Jewish Museum, 1992),1-9. 


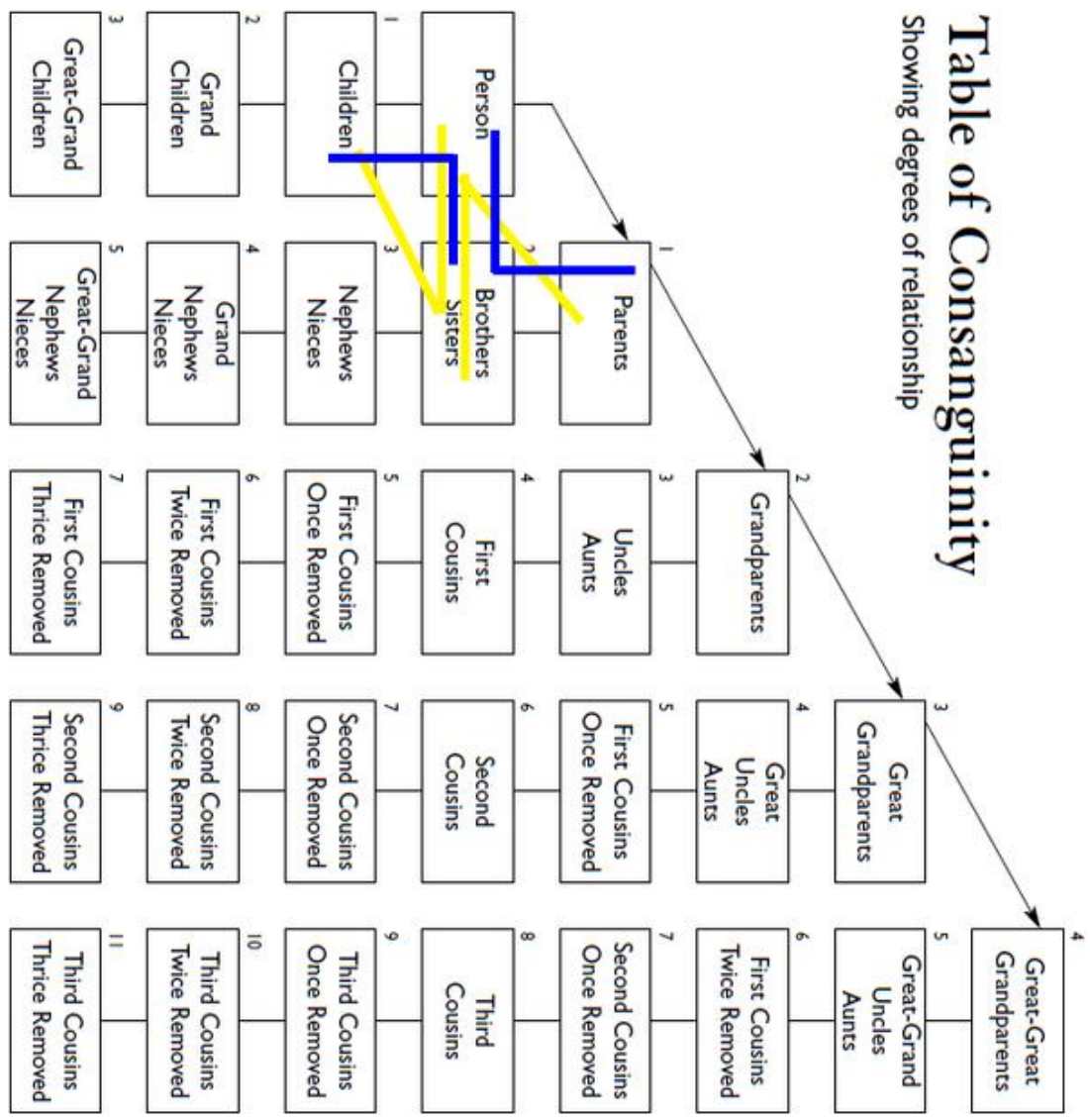

Fig. 14. Consanguinity Table (Yellow, V' annotations to Brother-Person-Father and Person-Sister-Daughter, Blue ,L' annotations to Person-Brother-Father and Sister-Person-Daughter by author to original licensed under Wikipedia Creative

Commons and creator Sg647112c, By Sg647112c - Own work, CC BY-SA 3.0, https://commons.wikimedia.org/w/index.php?curid=18790549)

This study, which has dealt with the category and identity of the isolated woman is important, but needs to be followed by a study that treats the portal as a material community. To equalize this study, there needs to be a material study looking at the portal as a material hybridity aligned with the birth of Alfonso VI's son, Sancho Alfónsez, whose 
mother, Zaida, was a Muslim woman, and whom Alfonso VI intended to inherit the throne. The alignment of the two physically-different races makes physical hybridity of his body (like the portal) a statement in favour of diversity. ${ }^{94}$ This would also entail an investigation of Arabic sources that claim Alfonso VI alluded to himself as 'Emperor of 'Two Religions' (al-Imbratür dhi-l-Millatayn) and the literature debating the veracity of these sources. ${ }^{95}$ But with the death of his son and with the addition of conceptual changes, there remains a dangerous ideology of conversion present in the symbolism of the Woman with the Skull and her conceptual imposition on real historical persons. The real cost of this type of imposition still resounds in societal stereotypes today. The pipe-dream of 'wholeness' that haunts Christianity's history and its representative actions makes the Woman with the Skull's undrilled eyes seek sight (Fig. 2) and the unresponsive frontal Mary of the Adoration (Fig. 10), who is spoken to by Magi to her proper right, seek hearing similar to Adam and Eve. The ambiguous physical history of the women in Alfonso VI's life serve in their suffering to be offered up to an impossible end to Christian ideological and faculty-based ambiguity.

\section{Bibliography}

\section{Primary Sources}

Apuleius- Commentary on Aristotle's Perihermaneias. Philadelphia (Schoenberg Collection MS ljs 101, folio 38r, 850 C.E.), http:/ /dla.library.upenn.edu/dla/medren/pageturn.html?q=ljs+101

94 In a council of January 1103, Sancho Alfónsez was named heir to León-Castille. Reilly, The Kingdom of León-Castilla under King Alfonso VI, 313.

${ }^{95}$ For the debate about the title of 'Emperor of the Two Religions,' see the following: Huici Miranda, Ambrosio. Las grandes batallas de la Reconquista durante las invasiones africanas (almoravides, almohades y benimerines). Madrid: Instituto de Estudios Africanos, Consejo Superior de Investigaciones Científicas, 1956, pp. 37-44. Angus Mackay and Muhammad Benaboud, "The Authenticity of Alfonso VI's Letter to Yusuf b. Tšufn," Al-Andalus 43(1978): 231-37; "Alfonso VI of León and Castile, 'Al-Imbratr-dh-lMillatayn,"' Bulletin of Hispanic Studies 56 (1979): 95-102; "Yet again Alfonso VI, 'the Emperor, Lord of [the Adherents of the Two Faiths, the Most Excellent Ruler': A Rejoinder to Norman Roth," Bulletin of Hispanic Studies 61 (1984): 171- 81, have argued with Norman Roth, "Again Alfonso VI, 'Imbartr dhu'l-Millatayn,' and Some New Data," Bulletin of Hispanic Studies 61(1984): 165-69. 
\&id=MEDREN_5186550\&rotation $=0 \&$ currentpage $=81$, (accessed 19.11.2017).

Augustine of Hippo (Augustinus Hipponensis). De peccatorum meritis et remissione et de baptism Paruulorum. Turnholt: Brepols, 2010. www.clt.brepolis.net/llta/pages/Toc.aspx?ctz-722774 (accessed 22.10.2017).

Catholic Church, and Erich Ludwig Eduard Caspar. Das Register Gregors VII. Monumenta Germaniae historica. Epistolae selectae.; Tomus II, Berlin: Weidmannsche Buchhandlung, 1920.

Clark, Willene B., ed. and trans. The Medieval Book of Birds: Hugh of Fouilloy's Aviarium. Binghamton: Medieval \& Renaissance Texts \& Studies, 1992.

Gerson, Paula, Annie Shaver-Crandell, Alison Stones, and Jeanne Krochalis, ed. and trans. The Pilgrim's Guide: A Critical Edition, Vol. II, The Text: Annotated English Translation. London: Harvey Miller Publishers, 1998.

Goswin of Mainz (Gozechinus). Epist ad Walcherum. PL 143, 885 - 908 (accessed 03.09.2017).

------. Apologiae Duae: Gozechini epistola ad Walcherum; Burchardi ut videtur, Abbatis Bellevallis apologia de barbis, ed. R. B. C. Huygens, intro Gilles Constable, CCCM 62 (Turnhout: Brepols, 1985), $11-43$.

The Holy Bible (Donay Rheims Version). Rockford: Tan Publishers, 1899. Hrosvit of Gandersheim. Hrotsvit: Opera Omnia. Ed. Walter Berschin. Munchen: K. G. Saur, 2001.

Isidore of Seville (Isidorus Hispalensis). Etymologiae, PL, 82 (accessed 30.09.2017).

. Etymologies of Isidore of Seville. Trans. Stephen A. Barney, W. J. Lewis, and J. A. Beach. Cambridge: Cambridge University Press, 2006.

. Etymologies. Madrid, Real. Acad. De la Hist., MS 76, fol 73v, 10 century

http://bibliotecadigital.rah.es/dgbrah/i18n/consulta/busqueda.cm d (accessed 19.11.2017)

C. Stephen Jaeger. "Appendix B: The Letter of Goswin of Mainz to his Student Walcher (ca. 1065)." In The Envy of Angels: Cathedral Schools and Social Ideals in Medieval Europe, 950 - 1200. Philadelphia:

University of Pennsylvania Press, 1994. 
John of Salisbury (Joannes Saresberiensis). Metalogicon, PL, 199 (accessed 19.11.2017).

. Metalogicon: a twelfth-century defense of the verbal and logical arts of the

Trivium. Trans. Daniel D. McGarry. Berkeley: University of California Press, 1955.

Martianus Capella- Martianus Capella and the Seven Liberal Arts. Vol. II. The Marriage of Philology and Mercury. Trans. William Harris Stahl, Richard Johnson, and E. L. Burge. New York: Columbia University Press, 1977.

Orosius, Commonitorium Orosii et Sancti Avrelii Augustini contra Priscillianistas et Origenistas. Ed. Klaus-D. Daur, CChr XLIX. Turnholt: Brepols, 1985.

Paul the Deacon (Paulus Diaconus). Pauli Historia Langobardorum. Monumenta Germaniae Historica, 48. Hannover: Hahnsche Buchhandlung, 2005.

Rey, Emma Falque, ed. Historia Compostellana. Turnholt: Brepols, 1988. Stones, Alison, Jeanne Krochalis, Paula Gerson, and Annie ShaverCrandell, ed. The Pilgrim's Guide: A Critical Edition. Vol. I, The Manuscripts: Their Creation, Production and Reception. London: Harvey Miller Publishers, 1998.

Thomas the Britain. The Romance of Tristam and Ysolt. Trans. Roger Sherman Loomis. New York: E. P. Dutton and Co., 1923. https://babel.hathitrust.org/cgi/pt?id=mdp.39015009017115;view $=1$ up;seq $=9$ (accessed 03.09.2017).

"Wheel of Fortune," Tegumentis adglutinata sunt fragmenta liturgica neumata manus s. XIII., Vienna, Österreichesche Nationalbibliothek, MS 2642, fol 11r, 1240-1260 http://search.obvsg.at/primo_library/libweb/action/display.do?tab $\mathrm{s}=$ detailsTab\&ct $=$ display $\& \mathrm{fn}=\mathrm{search} \& \mathrm{doc}=\mathrm{ONB} \_$aleph_onb06000 162018\&ind $x=1 \&$ recIds=ONB_aleph_onb06000162018\&recIdxs= $0 \&$ elementId $=0 \&$ renderMode $=$ poppedOut\&displayMode $=$ full \&frb $\mathrm{rVersion}=\& \mathrm{frbg}=\& \& \mathrm{vl}(1 \mathrm{UI} 0)=$ contains $\& \mathrm{dscnt}=0 \&$ scp.scps $=$ scope $\% 3 \mathrm{~A} \% 28 \mathrm{ONB}$ aleph_hanna $\% 29 \& \mathrm{tb}=\mathrm{t} \& \mathrm{vid}=\mathrm{ONB} \&$ mode $=$ Basic $\&$ srt $=$ rank\&tab $=$ onb_hanna\&dum $=$ true $\& v l($ free $T$ ext 0$)=2642 \& d s t$ $\mathrm{mp}=1479567433382$

William of Conches (Guillelmus de Conchis). Dragmaticon Philosophiae. Turnhout: Brepols, 2001. 
- A Dialogue on Natural Philosophy (Dragmaticon philosophiae). Ed. and trans. Italo Ronca and Matthew Curr. Notre Dame: University of Notre Dame Press, 1997.

\section{Secondary Sources}

Ainaud, Juan. Romanesque Painting. New York, 1963.

Azcárate, José María de. "La portada de las platerías y el programa iconográfico de la catedral de Santiago." Archivo español de arte, 36 (1963): 1-20.

Barber, Richard. Bestiary: being an English version of the Bodleian Library Oxford MS Bodley 764: with all the original miniatures reproduced in facsimile. Woodbridge: Boydell Press, 1992.

Blumenthal, Uta-Renate. The Investiture Controversy: Church and Monarchy from the Ninth to the Twelfth Century, trans. Uta-Renate Blumenthal. Philadelphia: University of Pennsylvania Press, 1988).

Bouchard, Constance Brittain. "Eleanor's Divorce from Louis VII: The Uses of Consanguinity." In Eleanor of Aquitaine: lord and lady, ed. Bonnie Wheeler and John Carmi Parsons, 223 - 235. New York: Palgrave Macmillan, 2003.

Cabrera, J. M., I. Seara, and J. de Miguel. "Portada de las Platerías: Catedral de Santiago de Compostela." Ars sacra, 38 (2006): 22-37.

Cahn, Walter. "Romanesque Sculpture and the Spectator." In The Romanesque Frieze and its Spectator: The Lincoln Symposium Papers, ed. Deborah Kahn, 45 - 60. London: Harvey Miller Publishers, 1992.

Castiñeiras González, Manuel A. "Arte románico y reforma eclesiástica." Las religiones en la historia de Galicia. 7 - 8 (1996): 307332, http://dspace.usc.es/handle/10347/4735 (accessed 19.11.2017).

. "Didacus Gelmirius, Patron of the Arts. Compostela's Long Journey: from the Periphery to the Center of Romanesque Art." In Compostella and Europe: The Story of Diego Gelmirez, 32 - 97. Milano: Skira, 2010.

. "La catedral románica: tipología arquitectónica y narracion visual." In Santiago, la Catedral y la memoria del arte, ed. Manuel Núnez and Andres A. Rosende Valdes, 39 - 96. Santiago de Compostela: Consorcio de Santiago, 2000

Castro, Américo. España en su historia: cristianos, moros y judios. Buenos Aires: Losada, 1948. 
Caviness, Madeline. "Images of Divine Order and the Third Mode of Seeing." Gesta 22/2 (1983): 99-120.

Chase, Michael. “The Medieval Posterity of Simplicius' Commentary on the Categories: Thomas Aquinas and Al-Fārābī.” In Medieval

Commentaries on Aristotle's Categories, ed. Lloyd A. Newton, 9-29.

Leiden: Brill, 2008.

Georges, Duby. Medieval Marriage: Two Models from Twelfth-Century France, trans. Elbord Forster. Baltimore: John Hopkins University Press, 1978.

Dunn, Maryjane and Linda Kay Davidson. The Pilgrimage to Santiago de Compostela: A Comprehensive, Annotated Bibliography. New York:

Garland Publishing, 1994.

Durliat, Marcel. La sculpture romane de la route de Saint-Jacques. Mont-deMarsan: Comité d'Études sur l'Histoire et l'Art de la Gascogne, 1990.

Ferguson, John. Pelagius: A Historical and Theological Study. Cambridge: W. Heffer \& Sons, Ltd., 1956.

Fernández González, A. "Un Viejo plano olvidado en el Archivo de la Catedral de Santiago: la Porta Francigena, su atrio y la Corticela en el año 1739." Compostellanum, XLVIII, 1 - 4 (2003): 701-742.

Focillon, Henri. L'Art de sculpteurs romans. Paris, 1931.

Glick, Thomas F. "Convivencia: An Introductory Note.” In Convivencia: Jews, Muslims, and Christians in Medieval Spain, ed. Vivian B. Mann, Thomas F. Glick, Jerrilynn D. Dodds. New York: Jewish Museum, 1992.

Gudiol, J. Die Kunst kataloniens. Vienna, 1937.

Häfner, Elizabeth. Die Wormser Briefsammlung des 11. Jabrbunderts, Erlanger Abhandlungen zur mittleren und neueren Geschichte 22, ed. Walthur Bulst. Erlangen: Palm and Enke, 1935.

Hearn, M. F. Romanesque Sculpture: The Revival of Monumental Stone Sculpture in the Eleventh and Twelfth Centuries. Ithaca: Cornell University Press, 1981.

Huici Miranda, Ambrosio. Las grandes batallas de la Reconquista durante las invasiones africanas (almoravides, almohades y benimerines). Madrid:

Instituto de Estudios Africanos, Consejo Superior de Investigaciones Científicas, 1956.

Iglesias Costa, Manuel. Roda de Isabena. Jaca: Monografias del Instituto de Estudios Pirenaicos, 1980. 
International Medieval Congress, Leeds, 2015. “Ambiguous Women in Medieval Art." Sessions 1503 and 1603, https://imc.leeds.ac.uk/dbsq102/AQueryServlet?*context=IMC\&*i $\mathrm{d}=10 \& *$ formId $=1 \& *$ request $T$ ype $=$ query $\&$ conference $=2015 * *$ servl etURI=https://imc.leeds.ac.uk/dbsq102/AQueryServlet.

C. Stephen Jaeger. The Envy of Angels: Cathedral Schools and Social Ideals in Medieval Europe, 950 - 1200. Philadelphia: University of Pennsylvania Press, 1994.

Ladner, Gerhart. "The Concepts of "Ecclesia" and "Christianitas" and their Relation to the Idea of Papal "Plenitudo Potestatis" from Gregory VII to Boniface VIII.” In Miscellanea Historiae Pontificiae, Vol. XVIII. Rome: Facultate Historiae Ecclesiasticae in Pontificia Universitate Gregoriana, 1954.

Loomis, Roger Sherman. "Introduction." In The Romance of Tristam and Ysolt. New York: E. P. Dutton and Co., 1923.

Lyman, Thomas W. "Motif et narratif: vers une typologie des thèmes profans sur la sculpture monumentale sur la romanias." Les cabiers de St. Michel-de-Cuxa, 10 (1979): 59-79.

Mackay, Angus and Muhammad Benaboud. "Alfonso VI of León and Castile, 'Al-Imbratr-dh-1-Millatayn."' Bulletin of Hispanic Studies 56 (1979): 95-102.

. "The Authenticity of Alfonso VI's Letter to Yusuf b. Tšufn." Al-Andalus 43(1978): 231-37. . "Yet again Alfonso VI, 'the Emperor, Lord of [the Adherents of the Two Faiths, the Most Excellent Ruler': A Rejoinder to Norman Roth." Bulletin of Hispanic Studies 61 (1984): 171-81.

Martin, Thérèse. Queen as King: Politics and Architectural Propaganda in Twelfth-Century Spain. Leiden: Brill, 2006.

Mathews, Karen Rose. "'They wished to destroy the temple of God": Responses to Diego Gelmírez's cathedral construction in Santiago de Compostela, 1100 - 1140." PhD diss., The University of Chicago, December 1995, accessed 29.09.2017, ProQuest Dissertations \& Theses.

Mora, Bernadette. "Signum Leonis, Signum Arietis." Annales du Midi: revue archéologique, historique, et philologique de la France méridionale 103/196 (1991): 483-489, http:/ /www.persee.fr/doc/anami_00034398_1991_num_103_196_7611 (accessed 19.11.2017). 
Moralejo, Serafín. "Cat. 92: Column Shaft decorated with Putti Gathering Grapes." In The Art of

Medieval Spain: AD 500 - 1200, 212-214. New York: The Metropolitan Museum of Art, 1993. . "Codex Calixtinus as an Art Historical Source." In The Codex Calixtinus and the Shrine of St. James, ed. John Williams and Alison Stones. Tübingen: G. Narr, 1992.

Næsgaard, Ole. Saint-Jacques de Compostelle et les débuts de la grande sculpture vers 1100. Aarhus: Universitetsforlag, 1962.

O’Callaghan, Joseph F. “The Integration of Christian Spain into Europe: the Role of Alfonso I of León-Castile." In Santiago, SaintDenis, and Saint Peter: The Reception of the Roman Liturgy in León-Castile in 1080, ed. Bernard F. Reilly. New York: Fordham University Press, 1985.

O'Meara, Carra Ferguson. The Iconography of the Façade of St. Gilles-duGard. New York: Garland Publishing, 1977.

The Online Etymology Dictionary, http://www.etymonline.com/ (accessed 29.09.2017).

Oxford English Dictionary. Oxford: Oxford University Press, 2013.

Palol, Pedro de and M. Hirmer. Early Medieval Art in Spain. London: Thames and Hudson, 1967.

Pickering, F. P. Literature and Art in the Middle Ages. Coral Gables: University of Miami Press, 1970.

Piesk, Tillman. "Square of Opposition," Own work, CC BY-SA 3.0 (By Watchduck (a.k.a. Tilman Piesk), Public Domain, https:/ / commons.wikimedia.org/w/index.php?curid=15516281)

Rees, B. R. Pelagius: Life and Letters. Woodbridge: Boydell Press, 1998.

Reilly, Bernard F. The Kingdom of León-Castilla under King Alfonso VI, 1065 - 1109. Princeton: Princeton University Press, 1988.

. The Kingdom of León-Castilla under Queen Urraca: 1109 - 1126. Princeton: Princeton University Press, 1982.

Roth, Norman. "Again Alfonso VI, 'Imbartr dhu'l-Millatayn,' and Some New Data." Bulletin of Hispanic Studies 61(1984): 165-69.

Rückert, Claudia. "A Reconsideration of the Woman with the Skull on the Puerta de las Platerías of Santiago de Compostela Cathedral." Gesta 51/2 (September 2012): 129-146. http:/ / www.journals.uchicago.edu.pitt.idm.oclc.org/toc/ges/2012/ $51 / 2$ (accessed 29.09.2017). 
Sage, Augustin. "Péché original. Naissance d'un dogme." In Doctrines of Human Nature, Sin and Salvation in the Early Church, ed. Everett Ferguson. 131 - 168, 211 - 248. New York: Garland Publishing, 1993.

Sastre Vázquez, Carlos. "La Portada de las Platerías y la "mujer adúltera": una revisión." Archivo español de Arte, $79 / 314$ (2006): 169186, http://xn--archivoespaoldearte53b.revistas.csic.es/index.php/aea/issue/view/2 (accessed 29.09.2017).

Sauerländer, Willibald. "Romanesque Sculpture in its Architectural Context." In The Romanesque Frieze and its Spectator: The Lincoln Symposium Papers, ed. Deborah Kahn, 17 - 44. London: Harvey Miller Publishers, 1992. . "Romanesque Sculpture in its Architectural Context." In

Romanesque Art: Problems and Monuments (Volume 1), ed. Willibald Sauerländer. 1 - 35. London: Pindar Press, 2004.

Schapiro, Meyer. "A Note on the Inscription of the Cathedral of

Santiago de Compostela." Speculum 17:2 (April 1942): 261 -262. Sg647112c, "Diagram of Consanguinity," original licensed under Wikipedia Creative Commons and creator Sg647112c, By Sg647112c - Own work, CC BY-SA 3.0, https://commons.wikimedia.org/w/index.php?curid=18790549). Stahl, William Harris, Richard Johnson, and E. L. Burge. Martianus Capella and the Seven Liberal Arts. Vol. I: The Quadrivium of Martianus Capella: Latin Traditions in the Mathematical Sciences 50 B.C. - AD 1250 with a Study of the Allegory and the Verbal Disciplines. New York, Columbia University Press, 1971. Stock, Brian. Myth and Science in the Twelfth Century: A Study of Bernard Silvestris. Princeton: Princeton University Press, 1972. Snyder, James. "Jan van Eyck and Adam's Apple." Art Bulletin, 58/4 (1976): 511-515.

Trinks, Stefan. "Sheela-na-gig Again: The Birth of a New Style from the Spirit of Pornography." In Pornographic Art and the Aesthetics of Pornography, ed. H. Maes, 162 - 182. London: Palgrave Macmillian, 2013.

Twomey, Lesley K. The Serpent and the Rose: The Immaculate Conception and Hispanic Poetry in the Late Medieval Period. Leiden: Brill, 2008. 
Valdez del Álamo, Elizabeth. "Cat. 86: Relief of Two Women with a Lion and a Ram." In Art of Medieval Spain, AD 500 - 1200, 205 206. New York: The Metropolitan Museum of Art, 1993.

Vallat, Phillippe. Farabi et l'école d'Alexandrie: Des prémisses de la conaissance à la philosophie politique. Paris: Librairie Philosophique J. Vrin, 2004.

Villa-Amil y Castro, José. La cathedral de Santiago: breve descripción histórica con la planta y un diseño iconográfico. Madrid: Tipografia de la Revista de Archivos, 1909.

Williams, John. "La Mujer del cráneo y la simbología románica." Quintana 2 (2003): 13-28. 